\title{
Original
}

Kaplan, J.O.; Krumhardt, K.; Ellis, E.C.; Ruddiman, W.F.; Lemmen, C.; Klein Goldewijk, K.:

Holocene carbon emissions as a result of anthropogenic land cover change

In: The Holocene (2010) SAGE Publications

DOI: $10.1177 / 0959683610386983$ 


\title{
The Holocene
}

http://hol.sagepub.com/

\section{Holocene carbon emissions as a result of anthropogenic land cover change}

Jed O. Kaplan, Kristen M. Krumhardt, Erle C. Ellis, William F. Ruddiman, Carsten Lemmen and Kees Klein Goldewijk

The Holocene 2011 21: 775 originally published online 30 December 2010

DOI: $10.1177 / 0959683610386983$

The online version of this article can be found at:

http://hol.sagepub.com/content/21/5/775

\author{
Published by: \\ @SAGE \\ http://www.sagepublications.com
}

Additional services and information for The Holocene can be found at:

Email Alerts: http://hol.sagepub.com/cgi/alerts

Subscriptions: http://hol.sagepub.com/subscriptions

Reprints: http://www.sagepub.com/journalsReprints.nav

Permissions: http://www.sagepub.com/journalsPermissions.nav

Citations: http://hol.sagepub.com/content/21/5/775.refs.html

>> Version of Record - Jul 29, 2011

OnlineFirst Version of Record - Dec 30, 2010

What is This? 


\title{
Holocene carbon emissions as a result of anthropogenic land cover change
}

\author{
Jed O. Kaplan,' Kristen M. Krumhardt,' Erle C. Ellis, ${ }^{2}$ William \\ F. Ruddiman, ${ }^{3}$ Carsten Lemmen ${ }^{4}$ and Kees Klein Goldewijk ${ }^{5}$
}

\begin{abstract}
Humans have altered the Earth's land surface since the Paleolithic mainly by clearing woody vegetation first to improve hunting and gathering opportunities, and later to provide agricultural cropland. In the Holocene, agriculture was established on nearly all continents and led to widespread modification of terrestrial ecosystems. To quantify the role that humans played in the global carbon cycle over the Holocene, we developed a new, annually resolved inventory of anthropogenic land cover change from 8000 years ago to the beginning of large-scale industrialization (AD I850). This inventory is based on a simple relationship between population and land use observed in several European countries over preindustrial time. Using this data set, and an alternative scenario based on the HYDE 3.1 land use data base, we forced the LPJ dynamic global vegetation model in a series of continuous simulations to evaluate the impacts of humans on terrestrial carbon storage during the preindustrial Holocene. Our model setup allowed us to quantify the importance of land degradation caused by repeated episodes of land use followed by abandonment. By 3 ka BP, cumulative carbon emissions caused by anthropogenic land cover change in our new scenario ranged between 84 and $102 \mathrm{Pg}$, translating to c. 7 ppm of atmospheric CO. By AD I850, emissions were 325-357 $\mathrm{Pg}$ in the new scenario, in contrast to 137-189 Pg when driven by HYDE. Regional events that resulted in local emissions or uptake of carbon were often balanced by contrasting patterns in other parts of the world. While we cannot close the carbon budget in the current study, simulated cumulative anthropogenic emissions over the preindustrial Holocene are consistent with the ice core record of atmospheric $\delta^{13} \mathrm{CO}_{2}$ and support the hypothesis that anthropogenic activities led to the stabilization of atmospheric $\mathrm{CO}_{2}$ concentrations at a level that made the world substantially warmer than it otherwise would be.
\end{abstract}

\section{Keywords}

agricultural intensification, anthropogenic land cover change, dynamic global vegetation model, global carbon cycle, Holocene $\mathrm{CO}_{2}$, prehistory

\section{Introduction}

Several attempts have been made to reconstruct the history of anthropogenically induced land cover change (ALCC), and in some cases the resulting $\mathrm{CO}_{2}$ emissions, both in the industrial era and in preceding centuries ( Houghton, 2003; Houghton et al., 1999; Klein Goldewijk, 2001; Pongratz et al., 2008; Ramankutty and Foley, 1998, 1999; Strassmann et al., 2008). Because most countries lack reliable land use surveys prior to the middle of the twentieth century, these reconstructions rely on hindcasting techniques based on estimated historical populations and assumptions about how people used the land. A common hindcasting method, linear scaling, first establishes the quantitative link between modern populations and land use data (typically within the interval 1960-2005) and then uses prior (historical) population data to estimate past land use by assuming near-constant land use per person (Klein Goldewijk, 2001; Klein Goldewijk et al., 2010a, b; Pongratz et al., 2008).

Land use estimates based on this assumption inevitably show little human land use prior to the exponential population explosion that began near AD 1500 and accelerated through the present day (Figure 1). This finding has led to the conclusion that forest clearance by humans could not have played a significant role in the gradual rise of $\mathrm{CO}_{2}$ concentrations that began during the middle Holocene about $8 \mathrm{ka}$ (cal. BP; $8000 \mathrm{yr}$ before AD 1950). Atmospheric $\mathrm{CO}_{2}$ increased by $\sim 22 \mathrm{ppm}$ from the $8 \mathrm{ka}$ minimum to the start of the industrial era (Ruddiman, 2007).
The assumption that land use per capita has remained constant over time is not supported by published evidence or by widely accepted land use theory. Archeologists, paleoecologists, paleobotanists, anthropologists, and other field-based researchers have repeatedly shown that from the late Paleolithic to the beginning of widespread industrialization, the first human residents and especially farmers in any region used far more land per person than those after them, and that land use per capita has decreased over time as populations increase, land availability per capita declines, technologies improve, and land use intensifies (e.g. Johnston, 2003; for reviews see, e.g. Kaplan et al., 2009; Ruddiman and Ellis, 2009). Indeed, Boserup (1965, 1981) synthesized evidence across field studies to develop the most widely used general model of land use intensification, in which population pressure drives farmers to implement ever-more innovative

\footnotetext{
'Ecole Polytechnique Fédérale de Lausanne, Switzerland

${ }^{2}$ University of Maryland Baltimore County, USA

${ }^{3}$ University of Virginia, USA

${ }^{4}$ Institut für Küstenforschung, Germany

${ }^{5}$ Netherlands Environmental Assessment Agency, The Netherlands
}

Received 7 June 2010; revised manuscript accepted 27 July 2010

Corresponding author:

Jed O. Kaplan, ARVE Group, Environmental Engineering Institute, Ecole Polytechnique Fédérale de Lausanne, Station 2, 1015 Lausanne, Switzerland Email: jed.kaplan@epfl.ch 


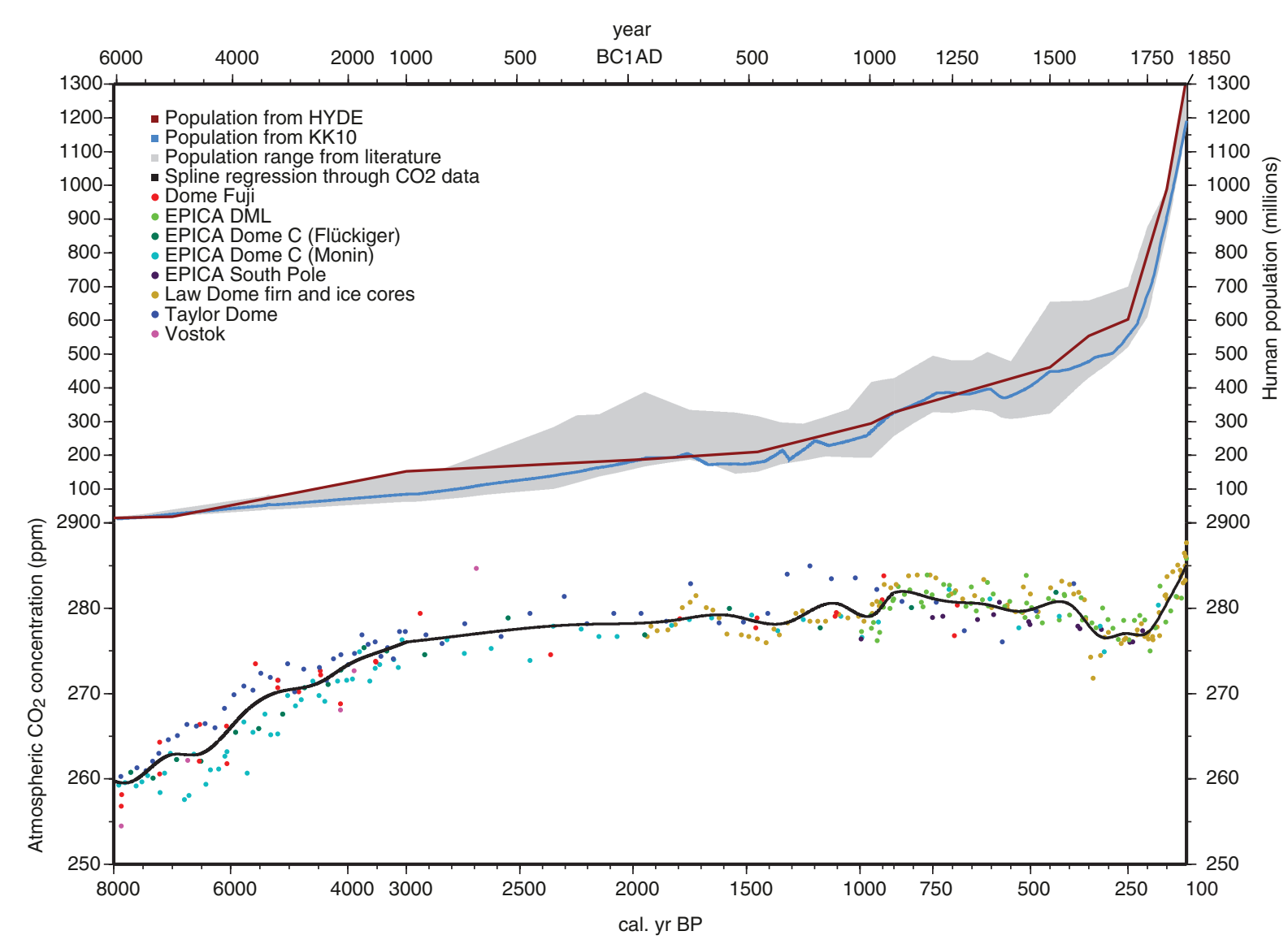

Figure I. Human population history and record of atmospheric $\mathrm{CO}_{2}$ concentrations from 8 ka to AD I850. Time series of population data from 209 regions was used to produce the KKIO ALCC data set. The gray area around the population estimates represents the range of population estimates in literature. The smoothed spline fit to ice core and firn $\mathrm{CO}_{2}$ records (see Krumhardt and Kaplan, 2010) was used to drive the LPJ DGVM

and labor-intensive methods of extracting more food per unit area farmed, so that land use per capita decreases as population density increases.

Regional historical observations from Europe and China support the theory that land cover change per capita fell sharply over at least the last 2000 years (Chao, 1986; Ellis and Wang, 1997; Ervynck et al., 2007; Hermy and Verheyen, 2007; Kaplan et al., 2009; McEvedy and Jones, 1978; Ruddiman, 2003; Ruddiman and Ellis, 2009; Ruddiman et al., forthcoming; Verheyen et al., 1999). In the earliest and least populated phase of the Holocene, most humans were hunter-gatherers, and practiced a nomadic or semi-sedentary lifestyle (e.g. Bellwood, 2005; Mazoyer and Roudart, 2006; Richerson et al., 2001). Under these conditions, forest clearing by fire was extensive, both from fires set intentionally to improve foraging conditions, and by the mere presence of humans with anthropogenic fire and livestock (for a review see Williams, 2008). Once agriculture was established, per capita land use decreased steadily. Ruddiman and Ellis (2009) summarized evidence on population and land clearing to suggest that per capita land use has decreased ten-fold since the mid Holocene. Likewise, in Lemmen's (2009) model of prehistoric technical and societal changes, per capita land use decreased by a factor of seven from the emergence of agriculture at $11 \mathrm{ka}$ to $3 \mathrm{ka}$.

In short, the assumption of constant land use per capita in preindustrial times is unjustified. Given that early farmers could have been using more than ten times as much land per capita as later ones, it is premature to conclude that human activities have played little or no role in the preindustrial (before $\mathrm{AD} 1850$ ) $\mathrm{CO}_{2}$ increase (Figure 1). Rather, simulations of preindustrial land use should take into account existing scientific knowledge and theory on how humans are known to have cleared land in the past. Such studies may then provide meaningful tests of the hypothesis that early agriculture caused the unprecedented interglacial $\mathrm{CO}_{2}$ increases observed 8000 years ago (Ruddiman, 2003; see also Ruddiman et al., forthcoming). Olofsson and Hickler (2008) made a first attempt in this direction, but their study assumed constant per capita land use after 1700, and it lumped earlier clearance into two categories: $90 \%$ clearance for 'states and empires', and very little clearance for all other 'agricultural groups'.

Here we reconstruct carbon emissions caused by ALCC over the Holocene based on contrasting scenarios of population and anthropogenic land use over time, including a new empirical model in which per capita ALCC declines over time and a conventional model that holds per capita ALCC roughly constant over time. These scenarios are used to drive a dynamic global vegetation model to estimate regional and global patterns of changes in terrestrial carbon storage through the last 8000 years. The resulting differences in global and regional patterns of ALCC and carbon emissions are then contrasted to highlight the global importance of assuming constant land use per capita versus 
models that incorporate changes in per capita land use with population density. Finally, we discuss how the ALCC emission estimates derived here relate to independent constraints on the global carbon cycle during the Holocene.

\section{Materials and methods}

In order to quantify ALCC emissions over the Holocene we (1) developed a new scenario of global ALCC from $8 \mathrm{ka}$ вP (calendar years before $\mathrm{AD} 1950$ ) to AD 1850 based on existing methodology, (2) assembled climate, soils and $\mathrm{CO}_{2}$ data used to drive a Dynamic Global Vegetation Model (DGVM), (3) modified the LPJ DGVM to handle ALCC and made several other small improvements to the model, and (4) ran the model in a number of experiments to characterize the range of possible emissions scenarios. Development of the new ALCC time series involved preparation of a new data base of estimates of prehistoric and historical global population. We assembled new driver data sets of $\mathrm{CO}_{2}$ concentrations and meteorology based on the latest available data sets. The modifications to the LPJ DGVM included a novel mechanism to simulate transient land use and shifting cultivation and an improved geographic distribution of soil organic matter based on compilation of observations. Methods specifically concerning our treatment of ALCC in the DGVM are described below. A detailed description of the rest of our methodology is contained in the supplementary material to this article, available online.

\section{Anthropogenic land cover change (ALCC)}

The primary driver of Holocene $\mathrm{CO}_{2}$ emissions in this study was a gridded time series of global ALCC. We used two ALCC data sets to drive LPJ DGVM, (1) the HYDE 3.1 data base (Klein Goldewijk et al., 2010b) and (2) a new data set developed for this study, hereinafter called the Kaplan and Krumhardt 2010 (KK10) data set. The KK10 scenario makes the central assumption that humans use land more intensively in all regions of the world with increasing population density and land scarceness (Boserup, 1965). In contrast, the standard version of the Historical Data base of the Global Environment (HYDE; Klein Goldewijk et al., 2010 b), is based on a nearly linear relationship between population and area of land under agriculture, and shows very little variation in per capita land use. Here, we use the HYDE 3.1 data set of ALCC (crop + pasture fractions) to provide a comparison to our results with the KK10 scenario and in order to compare our results with those from other carbon cycle studies that used the HYDE data set (e.g. Strassmann et al., 2008). In using HYDE as input to LPJ, we added the crop and pasture fractions of each gridcell and linearly interpolated between each timeslice. As the development and evaluation of the HYDE data base is described in detail in another publication (Klein Goldewijk et al., 2010b), here we focus the rest of this section on the description of the new KK10 data set.

An empirical model for simulating past ALCC was recently developed by Kaplan et al. (2009) and applied to Europe for the past 3000 years. We expanded on this method in the current study by expanding the geographic scope to global and the entire time period from 8000 years ago to AD 1850, when the Industrial Revolution began to profoundly alter relationships between population and land use (Ellis and Ramankutty, 2008). Uniquely, the Kaplan et al. (2009) method is based on a non-linear relationship between population density and land use, which generally translates to a decrease in per capita land use with time, as population densities increase and land use intensification occurs.

Human population is the main input for estimating ALCC using the KK10 model. We assembled a new, annually resolved data base of population from $1000 \mathrm{BC}$ to $\mathrm{AD} 1850$ for 209 regions of the world (Figures 1 and S1). A complete description of the methods used to assemble our historical population data base may be found in Krumhardt (2010). In summary, our population estimates are based primarily on McEvedy and Jones (1978), replaced or adjusted wherever better data were available. Adjustments to population estimates for Europe are discussed in Kaplan et al. (2009). For the Western Hemisphere before fifteenth-century contact with Europeans, we used updated values from a number of sources, all of which indicated that the McEvedy and Jones (1978) figures were generally at the very low range of estimates (Denevan, 1992; Krumhardt, 2010). Our data set therefore presents substantially increased population numbers for the pre-Columbian Western Hemisphere over those of McEvedy and Jones (1978). To capture spatial patterns in population changes across China, provincial data from $221 \mathrm{BC}$ to $\mathrm{AD} 1850$ was used (Zhao and Xie, 1988), allowing detailed improvements in population patterns and dynamics without changing total values significantly from McEvedy and Jones (1978). To extend our population time series for each region from $3 \mathrm{ka}$ back to $8 \mathrm{ka}$, we used a time series of global population simulated by the Global Land Use and Technological Evolution Simulator (GLUES; Lemmen, 2009; Wirtz and Lemmen, 2003).

We simulated ALCC based on population data, maps of land suitability for agriculture and pasture, and a simple relationship between population density and preindustrial land use (Kaplan et al., 2009). Time series of population estimates for each population region were transformed into the fraction of land used by people by first calculating population density on arable land within each region and then applying this value to a sigmoidal function that relates population density to the estimated area of land under deforestation. The amount of arable land in any population region is constrained by observationally based estimates of land suitability for cultivation and pasture at the present day (Ramankutty et al., 2002). In this sense, a limitation of our methodology is that we do not account for the way improvements in technology (e.g. irrigation, terracing, or the development of the steel plow) progressively opened up land to agricultural activities through time (Kaplan et al., 2009). While suitability for cultivation is a function of both climate and soil quality (Ramankutty et al., 2002), pasture suitability is determined only by climate, and accounts for areas suitable for grazing livestock as well as for wood harvest for construction or fuel (Kaplan et al., 2009). The spatial distribution of land use is determined by the total amount of land required for any region and time multiplied by the land suitability factor. This method results in maps of land use that display the most suitable land being cleared first, followed by use of increasingly marginal land as population pressure, and thus land required, increases. The population density-forest clearance relationship deteriorates with industrialization, urbanization and trade, and therefore the KK10 data set covers only the time period from 8 ka to AD 1850 . A detailed discussion of the methodology used to simulate ALCC is contained in Kaplan et al. (2009).

Because the original population density-ALCC relationship was developed using observations in Europe, and the potential productivity of land for agriculture and pasture is much higher in tropical regions and lower in boreal regions, it was necessary to 
add a potential productivity scaling to our population-ALCC model. Without this scaling, simulated ALCC in tropical regions was unrealistically high in prehistoric times, as even prehistoric societies were able to gain far higher yields in the tropics, even practicing double and sometimes triple cropping (Mathey and Gurr, 1983; Wilken, 1971). We used a high-resolution (5 arc-minute) map of potential Net Primary Productivity (NPP) for the midtwentieth century produced by the BIOME4 vegetation model (Kaplan, 2001) to rescale ALCC according to the potential productivity of land using the equation:

$$
\begin{aligned}
\mathrm{ALCC}= & \operatorname{ALCC}(1.5-\mathrm{NPP} / 1400) \\
& \mid \mathrm{NPP}>700 \mathrm{~g} / \mathrm{m}^{2} \text { per yr } \mid
\end{aligned}
$$

NPP is on average roughly twice as high in the most productive areas of the world (NPP $\sim 1400 \mathrm{~g} / \mathrm{m}^{2}$ per yr) than it is in most of Europe $\left(\sim 700 \mathrm{~g} / \mathrm{m}^{2}\right.$ per yr). To avoid overestimating ALCC in cool-temperate and boreal regions, and because these regions are not typically intensively exploited for agriculture in any case, this equation was applied only in areas with NPP exceeding the European average of $700 \mathrm{~g} / \mathrm{m}^{2}$ per yr (Kaplan, 2001).

The LPJ DGVM was run on a half-degree (30 arc-minute) grid, while both ALCC data sets have a native resolution of 5 arc-minutes. To prepare the ALCC data sets for the DGVM, we averaged each $6 \times 6$ block of $5^{\prime}$ gridcells to the $30^{\prime}$ grid used for LPJ.

\section{Other driver data for terrestrial carbon cycle modeling}

The LPJ DGVM is driven by spatially and temporally explicit data sets of climate, soil properties and atmospheric $\mathrm{CO}_{2}$ concentrations (Sitch et al., 2003). As the primary purpose of this study is to quantify the role of ALCC on the terrestrial carbon cycle, and because realistic global paleoclimate forcing data sets are currently neither available from climate models nor based on proxy reconstructions, we used a standard twentieth-century, observationbased climate data set to run LPJ: a 100-year long timeseries of global climate (monthly mean temperature and cloud cover, monthly total precipitation) gridded at $30^{\prime}$ resolution.

$\mathrm{CO}_{2}$ forcing data for LPJ was produced by compositing Antarctic ice-core and firn air records of atmospheric $\mathrm{CO}_{2}$ concentrations over the Holocene using a regression spline method weighted by the precision of the individual measurements (Krumhardt and Kaplan, 2010). The resulting annual timeseries of $\mathrm{CO}_{2}$ concentrations was used to drive the LPJ DGVM.

\section{Model configuration for ALCC simulations}

To model the effects of ALCC terrestrial vegetation in LPJ, we followed the approach of Strassmann et al. (2008), where managed and unmanaged land is represented on separate sub-grid scale tiles. We make the additional modification of explicitly simulating unmanaged land that was previously under land use, i.e. abandoned land. Thus, our LPJ model setup includes simultaneous simulation of up to three tiles in every $30^{\prime}$ pixel: (1) unmanaged land that has never been managed, (2) land under human land use, and (3) abandoned, recovering land. ALCC fractions are input on an annual time step and unmanaged land is always converted to land use preferentially before abandoned land is reused. Following Strassmann et al. (2008), conversion to agricultural land use (land clearance) from either the natural vegetation or the abandoned tile results in the transfer of all leaf biomass to the litter pool, immediate oxidation of $25 \%$ of the aboveground woody biomass, and redistribution of the rest of the wood to two product pools with exponential decay constants of 2 and 20 years, respectively. With land clearance, all living belowground biomass enters the litter pool immediately, and decays or is transferred to soil organic matter following Sitch et al. (2003). Even after conversion to agricultural land, a significant amount of the carbon in the ecosystem may remain in situ, mainly in the form of soil organic matter (for more details on the simulation of soil organic matter dynamics, see section 1.3 of the supplementary methods for this paper, available online). Following initial clearance of the agricultural land use tile, all woody PFTs are prevented from further establishment.

To incorporate shifting land use practices in our ALCC model, we further created a scheme for modeling the turnover of agricultural land that simulates progressive use, abandonment, and conversion of unused land, e.g. shifting cultivation. In this scheme, a land 'turnover-time' (tt) is specified in the model run options where $1 / \mathrm{tt}$ equals the fraction of the total area under human land use that is simultaneously abandoned and cleared at each annual time step. The total area under human land use at any given time is the same in all simulations, regardless of turnover time, though in simulations where $t \mathrm{t}$ is prescribed, a significant fraction of the gridcell can be in the abandoned tile. We defined an unusable fraction of each gridcell as $1-$ usable fraction, which is based on climate data and unique to each gridcell (Kaplan et al., 2009; Ramankutty et al., 2002). The unusable fraction always remains under natural vegetation, regardless of the turnover rate. For the simulations with the HYDE land use data, if the fraction of land under anthropogenic land use becomes greater than the calculated usable fraction, then the unusable fraction is reduced to reflect the remaining unused portion. We made experiments specifying turnover of agricultural land with 25-, 50- and 100-year rotation times, in which $4 \%, 2 \%$ or $1 \%$ of the land used is turned over annually on all gridcells with ALCC, respectively. Though people in the tropics often implemented shorter rotation times (Cook, 1921; Reina, 1967), performing runs on a global scale with 5-10 year agricultural rotation times would result in the same overall trends in carbon emissions we describe below but with unreasonably high absolute emissions, especially considering that farmers in temperate regions often cultivated the same plots of land continuously (Mazoyer and Roudart, 2006). We further ran a series of experiments as a control scenario where no land turnover is specified, i.e. agricultural land use was permanently established on the same fraction of the gridcell for the duration of the model run.

Model experiments were performed with the LPJ DGVM to simulate the ALCC effects on the carbon cycle over the Holocene. Each run is initialized with a 1000 year spinup period - the soil organic matter pools are analytically equilibrated after 750 years following Sitch et al. (2003) - and then starts at $8 \mathrm{ka}$ and continues to AD 1850, a transient run of 7901 years.

\section{Results}

\section{Scenarios of ALCC}

The two ALCC scenarios used in this study differ substantially (Table 1; Figures 2, 3, and S3). In general, the KK10 scenario, in which land use per capita declines as population density increases, 
Table I. Global land areas under ALCC for the KKIO scenario (this study) and the HYDE 3.I data base (Klein Goldewijk et al., 2010)

\begin{tabular}{|c|c|c|c|c|c|}
\hline \multirow[t]{2}{*}{ Year } & \multirow[t]{2}{*}{ Cal. yr BP } & \multicolumn{2}{|c|}{$\begin{array}{l}\% \text { global land under } \\
\text { ALCC }\end{array}$} & \multicolumn{2}{|c|}{$\begin{array}{l}\mathrm{km}^{2} \text { (millions) under } \\
\mathrm{ALCC}\end{array}$} \\
\hline & & KKIO & HYDE 3.1 & KKIO & HYDE 3.I \\
\hline $6050 \mathrm{BC}$ & 8000 & 1.3 & 0.015 & 1.86 & 0.021 \\
\hline $1050 \mathrm{BC}$ & 3000 & 6.1 & 1.2 & 8.71 & I.7 \\
\hline $50 \mathrm{BC}$ & 2000 & 9.5 & 1.9 & 13.6 & 2.81 \\
\hline$A D 100$ & 1850 & 10.1 & 2 & 14.4 & 2.93 \\
\hline AD 500 & 1450 & 10.7 & 1.9 & 15.3 & 2.78 \\
\hline$A D 950$ & 1000 & 12.6 & 2.3 & 18 & 3.38 \\
\hline AD 1473 & 477 & I6.I & 3.5 & 23 & 5.1 \\
\hline AD 1600 & 350 & I5.I & 4.3 & 21.6 & 6.24 \\
\hline AD 1850 & 100 & 20.7 & 9.9 & 29.4 & 14.4 \\
\hline
\end{tabular}

consistently produces higher levels of preindustrial ALCC than the HYDE data base (Klein Goldewijk et al., 2010b), which uses a relatively constant relationship between land use and population similar to mid-twentieth century levels. Additionally, in KK10, ALCC is more widely distributed within regions with high agricultural suitability, while HYDE generally depicts smaller, more concentrated areas of land clearance, probably because it uses a number of factors in addition to the climate and soil indicators used in KK10, including the location of urban areas, slope, and distance to water bodies (Klein Goldewijk et al., 2010b). The slight increase in per capita land use with time seen in HYDE (Figure 2) reflects the country-level trends in per capita land use observed during the late twentieth century upon which this data set is based. Over this time period, both increases and decreases in per capita land use are observed as a result of industrialization and technology, offset by development of export crops and increases in the area of irrigated farmland. Extrapolation of these trends to the past is generally unrealistic.

In the HYDE data base, a nearly pristine world existed until $3 \mathrm{ka}$ when clearing in northeast China, the Middle East, Europe and South America began to emerge (Table 1; Figure 3a). In contrast, the KK10 land use scenario simulates that these regions, in addition to parts of the Indian subcontinent and Mesoamerica, were up to $40 \%$ under human land use at this time period. 2000 years later, by $\mathrm{AD} 1, \mathrm{ALCC}$ only slightly increases in the HYDE data set, while in the KK10 scenario, lands of the Middle East and Indian regions were nearly $70 \%$ exploited. Moreover, the KK10 scenario shows that parts of Mesoamerica, the Andes, Europe and China were nearly $60 \%$ cleared and some parts of sub-Saharan Africa were up to $50 \%$ cleared at $\mathrm{AD} 1$.

From AD 1500 to AD 1600 a decrease in anthropogenic land use in the Western Hemisphere is visible in both data sets, as the indigenous populations of the Americas succumbed to disease and war brought by European explorers and colonists (Figure 3b). The collapse of large pre-contact populations with advanced agriculture, which were especially concentrated in Mesoamerica and the Andes, led to high amounts of land abandonment in the KK10 data set. The low levels of ALCC shown at AD 1500 in the HYDE scenario are almost entirely abandoned 100 years after conquest.

By AD 1800, anthropogenic land use in the Americas accelerated with the spread of colonies and nations founded by Europeans. The KK10 scenario shows the northeast United States and the

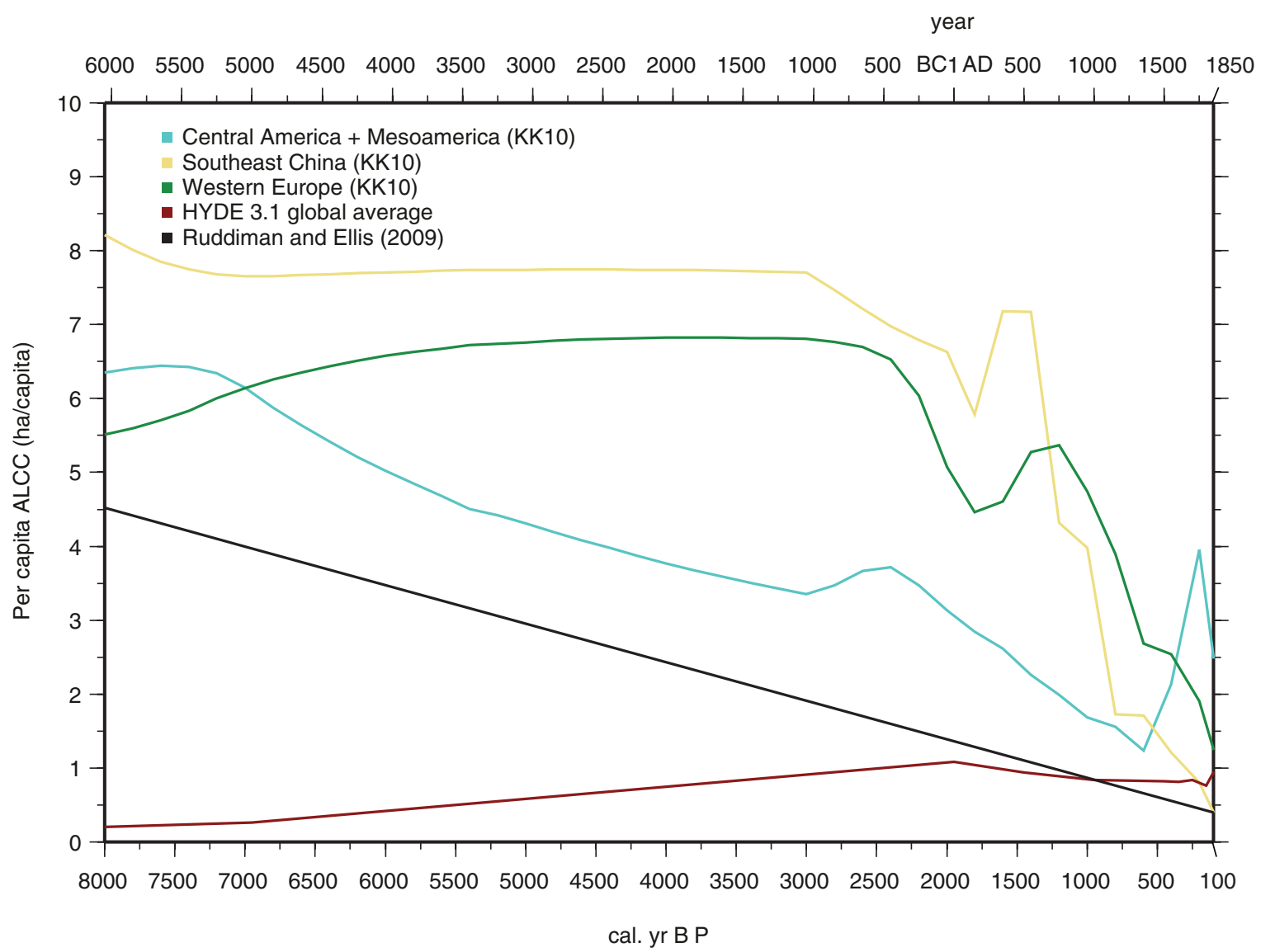

Figure 2. Per capita ALCC from 8 ka to ADI850 for western Europe (average of Italy, Spain, France, and Germany), southeast China (average of the provinces Fujian, Guangdong, Jiangsu, Jiangxi, Zhejiang, and Anhui), and the Mesoamerica-Central America regions from the KK 10 scenario, as well as global per capita ALCC from HYDE 3.I data base and from Ruddiman and Ellis (2009) 
Figure 3.

(a)

KK10, based on Kaplan et al. (2009)
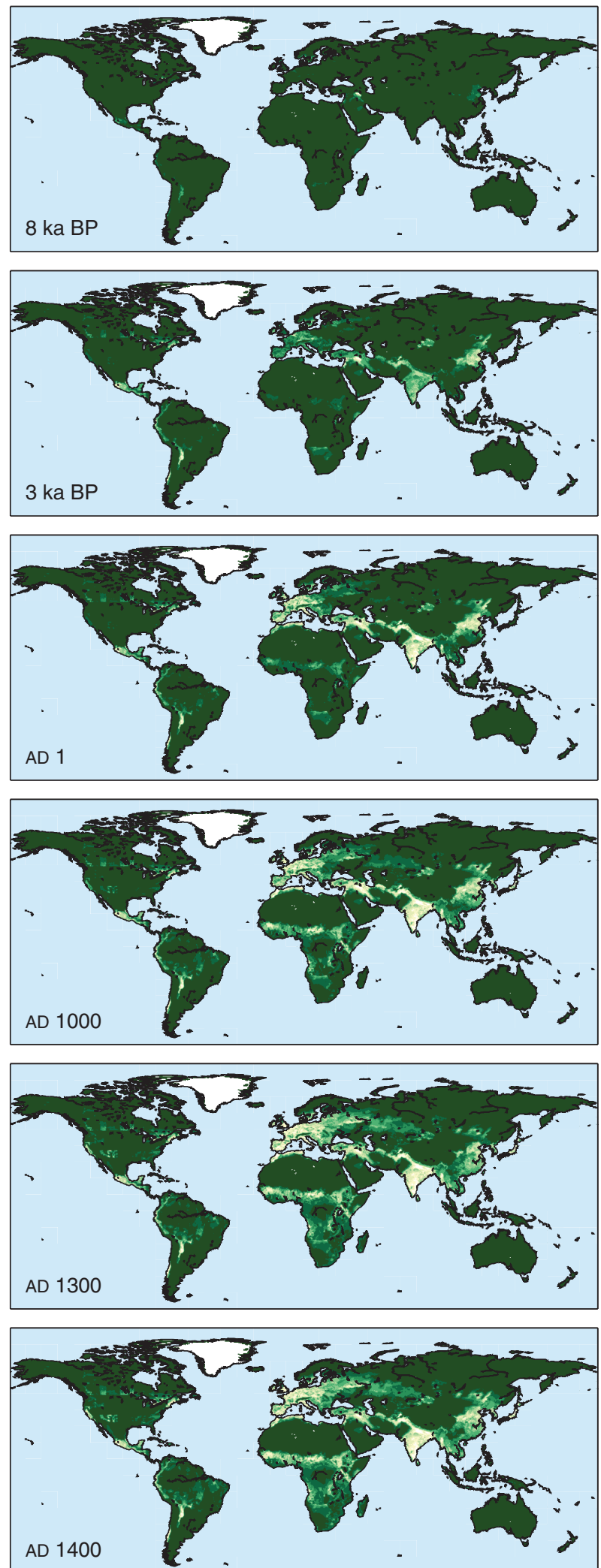

HYDE 3.1, crops + pasture
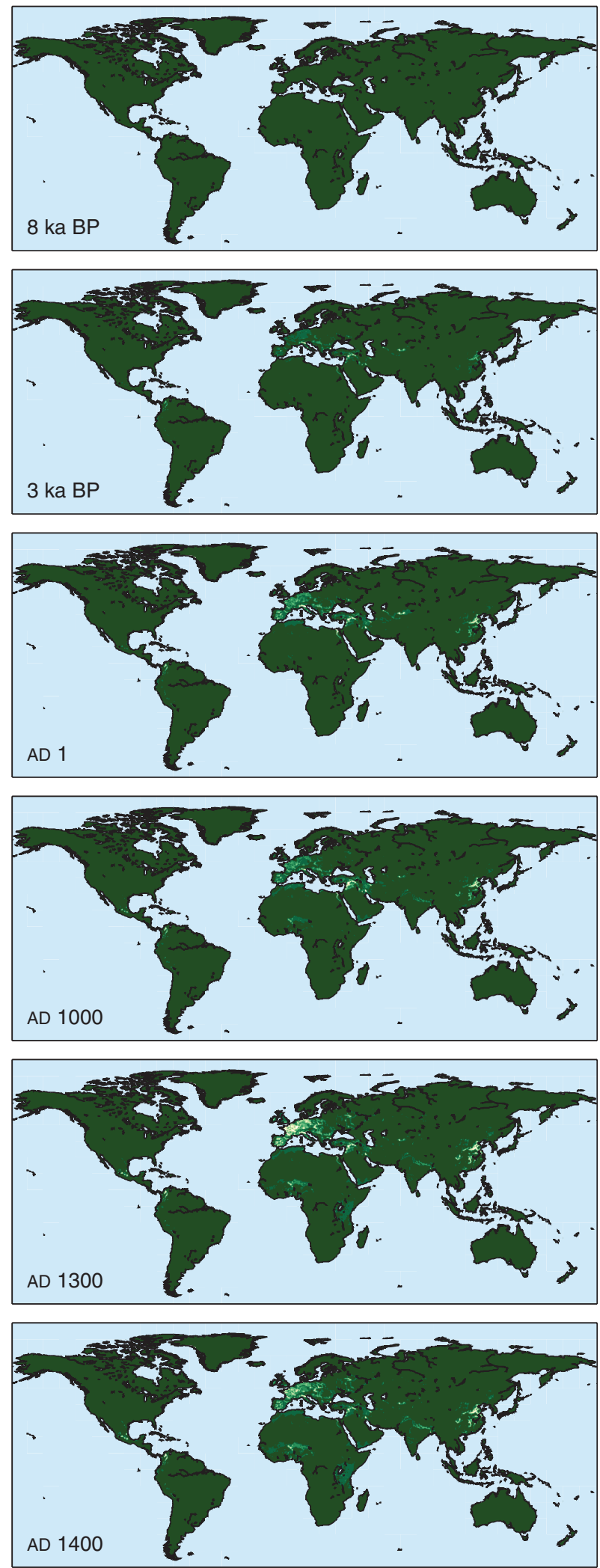

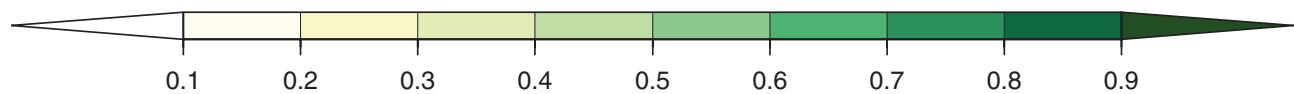

Fraction of gridcell under natural vegetation 
Figure 3. (Continued)

(b)

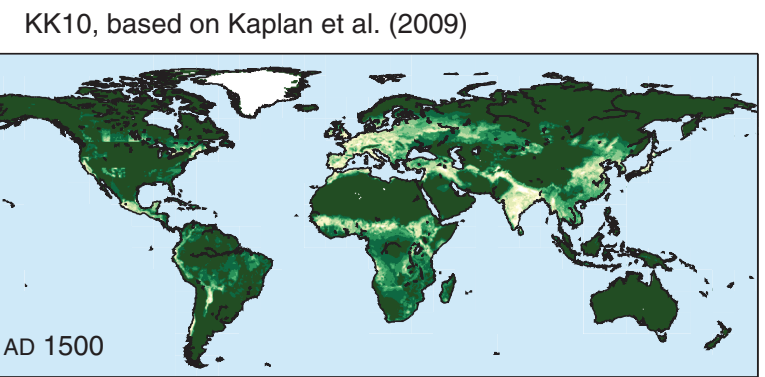

HYDE 3.1, crops + pasture
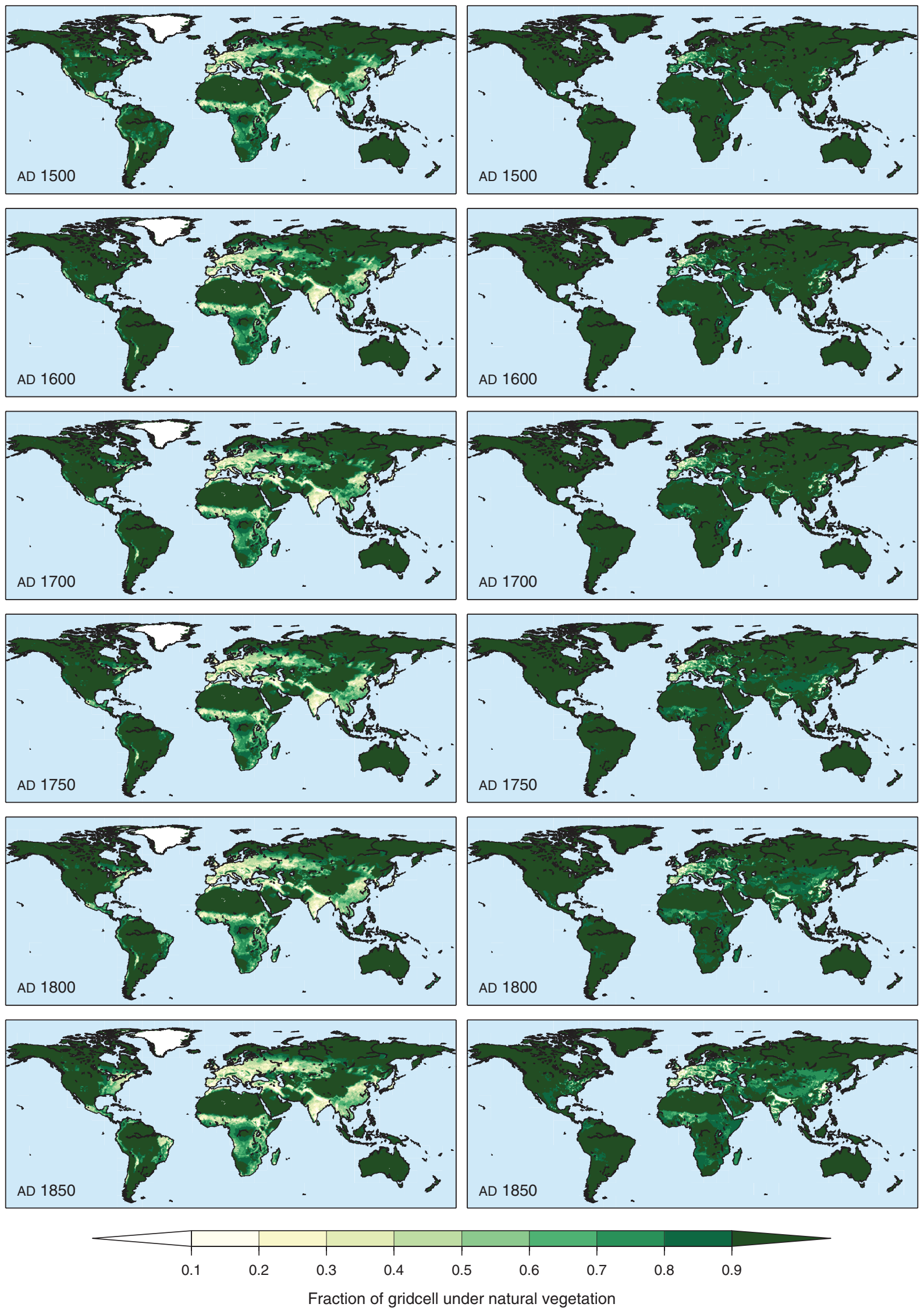
natural vegetation for the timeslices (a) 8 ka BP, 3 ka BP, AD I, AD 1000, AD I300, and AD I400, and (b) AD I500, AD I600, AD I700, AD I750, AD 1800 , and $A D 1850$ 
Figure 4.

(a)

KK10, based on Kaplan et al. (2009)
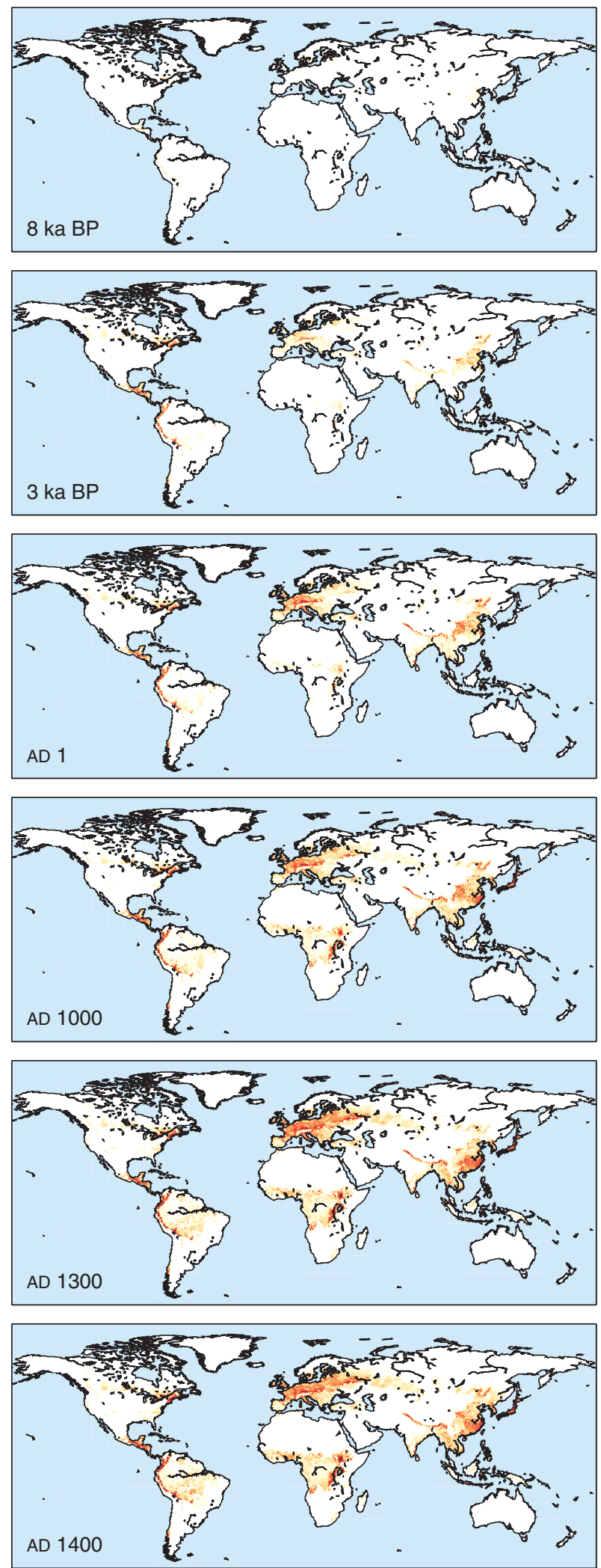

HYDE 3.1, crops + pasture
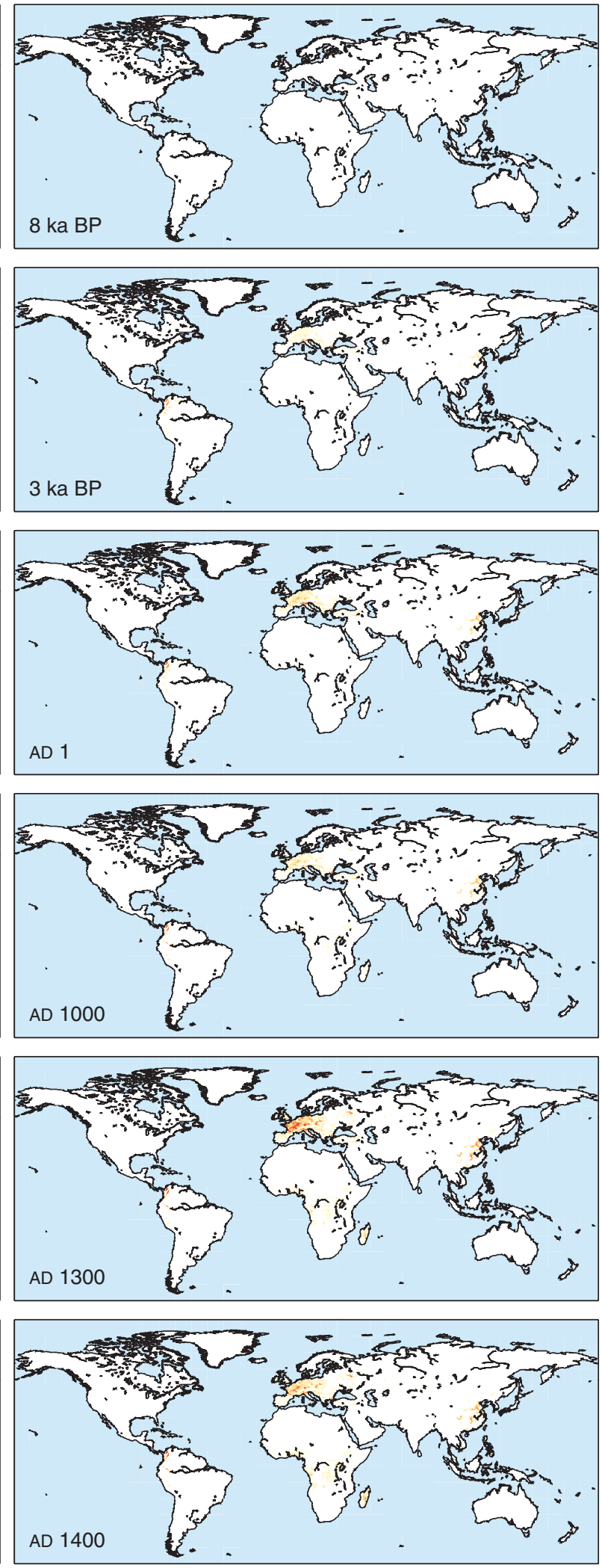

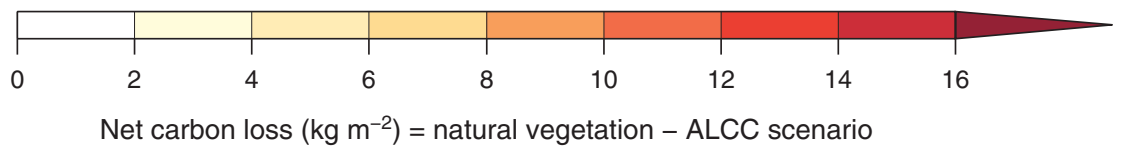


Figure 4. (Continued)

(b)

KK10, based on Kaplan et al. (2009)
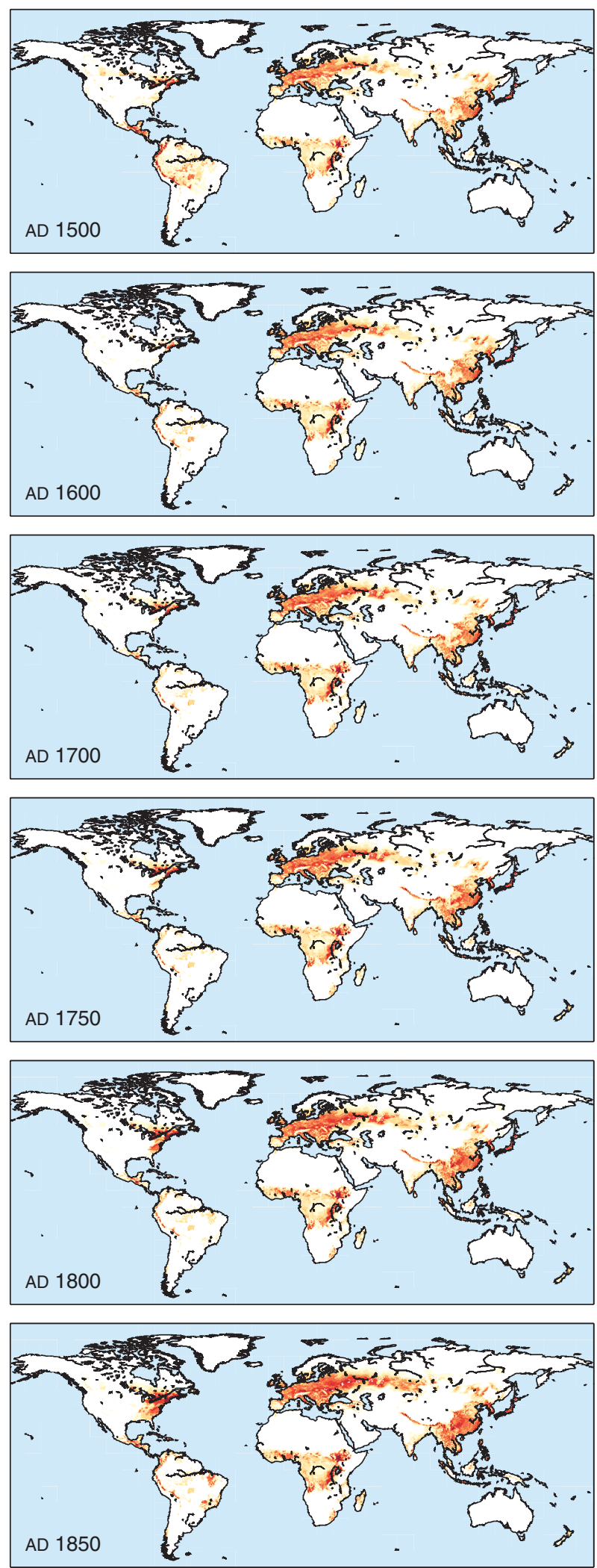

HYDE 3.1, crops + pasture
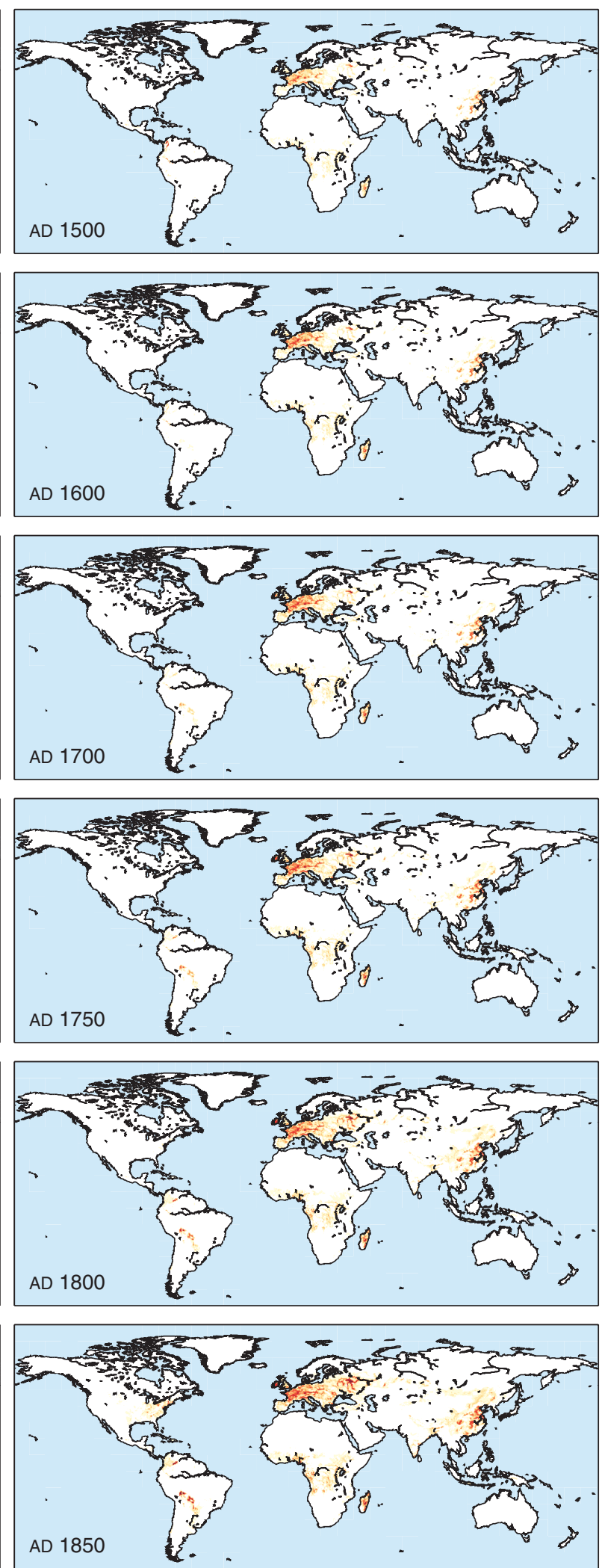

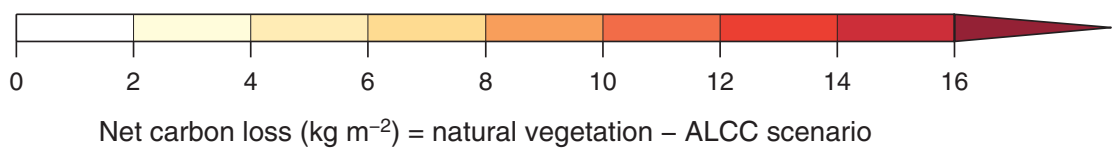

Figure 4. Maps of the difference in LPJ-simulated total terrestrial carbon storage between the ALCC scenarios and control run. Maps are for the same timeslices as those depicted in Figure 3 


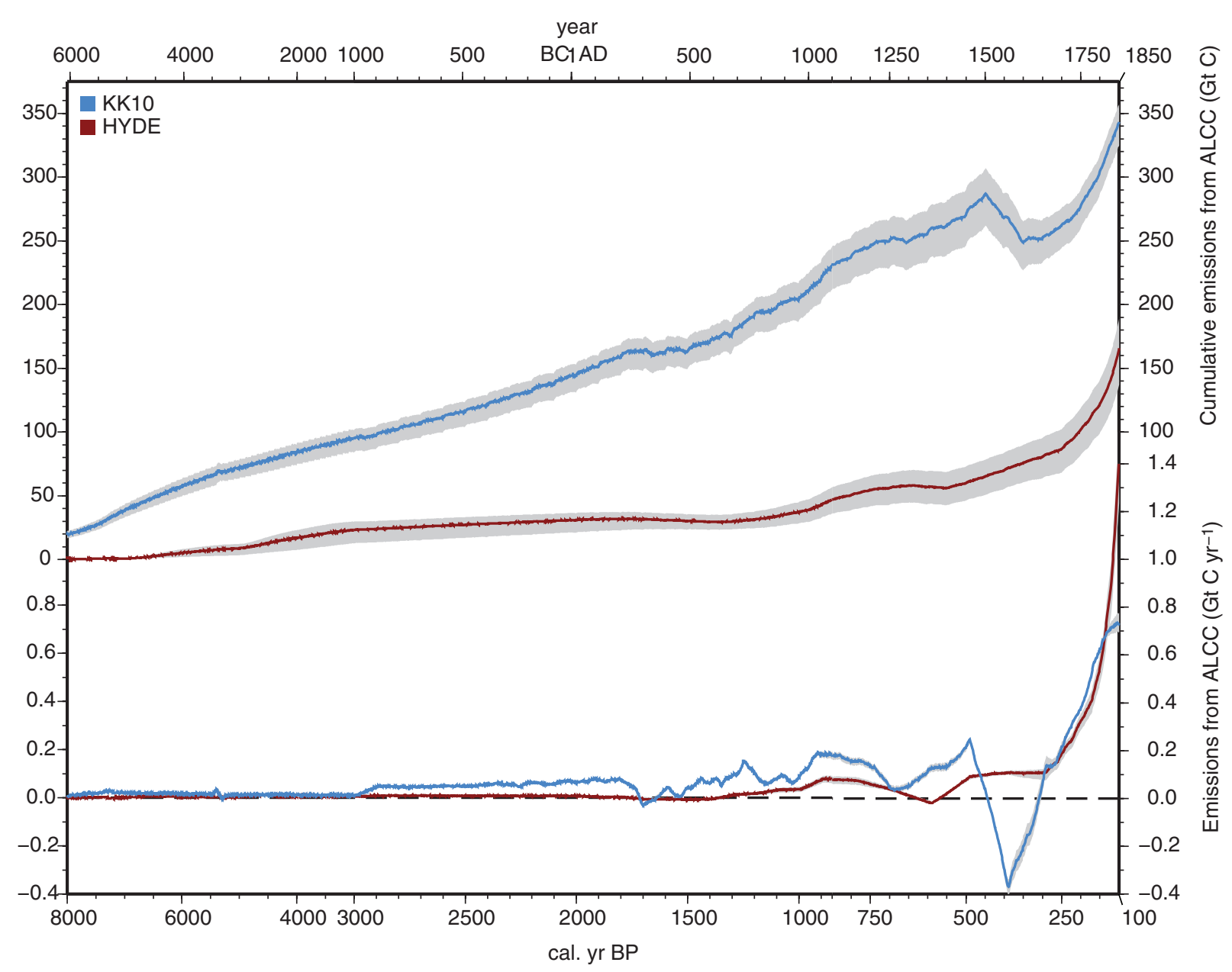

Figure 5. Cumulative carbon emissions (top; $\mathrm{Pg} C$ ) and annual emissions (bottom; $\mathrm{Pg} \mathrm{C} / \mathrm{yr}$ ) from $\mathrm{ALCC}$ resulting from LPJ DGVM runs using the KKIO and HYDE ALCC scenarios. The shaded gray area is represents the range from runs with 25 - and I00-year agricultural rotations and no rotation, while the colored lines represent runs with a 50-year agricultural rotation

eastern coast of Brazil to be $40 \%$ to $50 \%$ under agriculture by $\mathrm{AD}$ 1850. The HYDE data set shows only limited patches of land clearance over the eastern half of the United States, and no ALCC in eastern South America. There is also disagreement between ALCC data sets at this time period in Southeast Asia, Eastern Europe and the Middle East, where substantially more ALCC is depicted in the KK10 scenario. At AD 1850, the KK10 scenario simulates $\sim 21 \%$ of global land area $\left(29.4 \times 10^{6} \mathrm{~km}^{2}\right)$ under anthropogenic land use while in the HYDE scenario only $10 \%$ $\left(14.4 \times 10^{6} \mathrm{~km}^{2}\right)$ of land is used (Table 1; Figure S3).

\section{Geographic distribution of changes in carbon storage}

The amount of carbon emitted from ALCC in a region strongly depends on the vegetation that would exist there naturally. For example, at AD 1 on the Indian subcontinent, high levels of ALCC correspond with low levels of carbon loss in the southern part of the continent dominated by grassland or savanna, while lower levels of ALCC result in much greater carbon loss in the humid forest areas along southern foothills of the Himalaya (Figures 3a and 4a). Likewise, the relatively small amounts of ALCC in the densely forested landscapes around the St Lawrence Valley of North America and in Mesoamerica led to high amounts of carbon emissions as a result of ALCC (Figures 3 and 4; KK10 scenario). In the HYDE scenario, in all time periods, only Europe stands out as a significant source of carbon emissions from ALCC (Figure $4 \mathrm{a}, \mathrm{b})$. In this scenario, other areas of the world, such as China and the Americas, only start to result in substantial amounts of ALCC emissions during the last centuries of the model run.

\section{Global trends in carbon storage over the Holocene}

The large dissimilarity between the ALCC data sets is reflected in the time series of anthropogenic carbon emissions produced by the DGVM for each scenario. In Figure 5 the difference in terrestrial carbon storage between the ALCC scenarios and control run (with no ALCC) is presented. Cumulative carbon emissions from ALCC by AD 1850 range from 137 to $189 \mathrm{Pg}(1 \mathrm{Pg}=1 \mathrm{Gt})$ for the HYDE data set and from 325 to $357 \mathrm{Pg} \mathrm{C}$ for the KK10 data set, depending on the land turnover time (Figure 5; Table 2). The effect of $\mathrm{CO}_{2}$ fertilization is shown in Figure $\mathrm{S} 2$ as living biomass increased concurrently with the slow rise of $\mathrm{CO}_{2}$ during the Holocene for the control scenario.

Generally, HYDE-based simulations show that the majority of ALCC carbon emissions occurred during 500 years prior to industrialization, whereas in the KK10 scenario emissions from ALCC are more gradual and show significance beginning at $8 \mathrm{ka}$. As a result, cumulative emissions caused by preindustrial ALCC are much lower in the HYDE scenarios as compared to the KK10 scenarios (Table 3). Additionally, the implementation of ALCC 
Table 2. Cumulative carbon emissions from ALCC (Gt C) for the KKIO and HYDE ALCC scenarios for 25, 50, and I00-year agricultural rotations and no rotation

\begin{tabular}{|c|c|c|c|c|c|c|c|c|c|}
\hline \multirow[t]{3}{*}{ Year } & \multirow[t]{3}{*}{ Cal. yr BP } & \multicolumn{8}{|c|}{ ALCC emissions ( $\mathrm{Pg} \mathrm{C}$ ) } \\
\hline & & \multicolumn{4}{|l|}{ KKIO } & \multicolumn{4}{|c|}{ HYDE 3.1} \\
\hline & & $\begin{array}{l}25-y r \\
\text { rotation }\end{array}$ & $\begin{array}{l}50-y r \\
\text { rotation }\end{array}$ & $\begin{array}{l}100-y r \\
\text { rotation }\end{array}$ & $\begin{array}{l}\text { No } \\
\text { rotation }\end{array}$ & $\begin{array}{l}25-y r \\
\text { rotation }\end{array}$ & $\begin{array}{l}50-y r \\
\text { rotation }\end{array}$ & $\begin{array}{l}100-y r \\
\text { rotation }\end{array}$ & $\begin{array}{l}\text { No } \\
\text { rotation }\end{array}$ \\
\hline $6050 \mathrm{BC}$ & 8000 & 22 & 20 & 18 & 17 & 0 & 0 & 0 & 0 \\
\hline $1050 \mathrm{BC}$ & 3000 & 102 & 95 & 90 & 84 & 30 & 23 & 19 & 13 \\
\hline $50 \mathrm{BC}$ & 2000 & 154 & 145 & 139 & 132 & 36 & 31 & 27 & 21 \\
\hline AD 100 & 1850 & 166 & 156 & 150 & 143 & 37 & 32 & 28 & 23 \\
\hline AD 500 & 1450 & 179 & 169 & 162 & 155 & 35 & 30 & 26 & 24 \\
\hline AD 950 & 1000 & 218 & 204 & 196 & 187 & 45 & 37 & 33 & 28 \\
\hline$A D \mid 473$ & 477 & 298 & 279 & 267 & 254 & 76 & 62 & 55 & 48 \\
\hline AD 1600 & 350 & 265 & 249 & 239 & 227 & 90 & 76 & 67 & 61 \\
\hline AD 1850 & 100 & 357 & 343 & 334 & 325 & 189 & 166 & $15 \mid$ & 137 \\
\hline
\end{tabular}

Table 3. Total carbon stocks, carbon in living biomass, litter carbon, and soil carbon in global terrestrial ecosystems (Pg C) for the control scenario (natural vegetation), and the KKIO and HYDE ALCC scenarios for selected timeslices of the LPJ model runs. For the model runs with ALCC, values are means of 25,50, and 100-year agricultural rotations and no rotation, and the range around the mean is shown in parentheses

\begin{tabular}{|c|c|c|c|c|c|c|c|c|c|c|c|c|c|}
\hline \multirow[t]{3}{*}{ Year } & \multirow{3}{*}{$\begin{array}{l}\text { Cal. yr } \\
\text { BP }\end{array}$} & \multicolumn{12}{|c|}{ Carbon stock (Pg) } \\
\hline & & \multicolumn{4}{|c|}{ Control } & \multicolumn{4}{|l|}{ KKIO } & \multicolumn{4}{|l|}{ HYDE } \\
\hline & & Total & $\begin{array}{l}\text { Living } \\
\text { biomass }\end{array}$ & Litter & Soil & Total & $\begin{array}{l}\text { Living } \\
\text { biomass }\end{array}$ & Litter & Soil & Total & $\begin{array}{l}\text { Living } \\
\text { biomass }\end{array}$ & Litter & Soil \\
\hline $6050 \mathrm{BC}$ & 8000 & 3276 & 794 & 338 & 2144 & $3257(6)$ & 782 (8) & $336(0.4)$ & $2138(2)$ & $3276(6)$ & $794(0)$ & $338(0)$ & $2144(0)$ \\
\hline $1050 \mathrm{BC}$ & 3000 & 3396 & 843 & 348 & 2205 & $3303(18)$ & $785(30)$ & $340(2)$ & $2178(I \mid)$ & $3374(18)$ & $833(8)$ & $347(0.3)$ & $2194(10)$ \\
\hline $50 \mathrm{BC}$ & 2000 & 3411 & 850 & 349 & 2213 & $3269(22)$ & $764(38)$ & $336(2)$ & $2170(14)$ & $3382(22)$ & $834(\mathrm{II})$ & $346(I)$ & $2203(5)$ \\
\hline$A D 100$ & 1850 & 3427 & 846 & 360 & 2221 & $3274(23)$ & $753(40)$ & $346(3)$ & $2175(14)$ & $3397(23)$ & $829(11)$ & $358(I)$ & $2211(4)$ \\
\hline$A D 500$ & 1450 & 3430 & 847 & 360 & 2223 & $3263(24)$ & $746(44)$ & $345(3)$ & $2172(18)$ & 3401 (24) & 831 (II) & $358(1)$ & $2212(1)$ \\
\hline AD 950 & 1000 & 3420 & 854 & 348 & 2218 & $3218(31)$ & $732(5 \mathrm{I})$ & $331(3)$ & $2155(18)$ & $3384(31)$ & $835(12)$ & $346(1)$ & 2203 (5) \\
\hline AD 1473 & 477 & 3442 & 853 & 360 & 2229 & $3168(44)$ & $693(58)$ & 337 (3) & $2137(11)$ & 3382 (44) & $823(16)$ & $356(1)$ & 2203 (I2) \\
\hline AD 1600 & 350 & 3434 & 849 & 359 & 2226 & $3189(38)$ & 7II (55) & 337 (3) & 2141 (14) & $3360(38)$ & $814(17)$ & $353(1)$ & $2194(14)$ \\
\hline$A D 1850$ & 100 & 3426 & 857 & 350 & 2219 & 3087 (32) & $672(5 I)$ & $319(3)$ & 2096 (I5) & 3266 (32) & 785 (24) & 337 (2) & $2144(30)$ \\
\hline
\end{tabular}

Table 4. Preindustrial and Industrial carbon emissions $(\mathrm{Pg} \mathrm{C})$ due to ALCC comparing this study with other published results

\begin{tabular}{lc}
\hline Land use simulation & Pre- I850 \\
\cline { 2 - 2 } & Pg C \\
\hline Olson et al. (I983) & $240-540$ \\
DeFries et al. (1999) & $48-57$ \\
Strassmann et al. (2008) & 94 \\
Olofsson and Hickler (2008) & 114 \\
Pongratz et al. (2009) & 63 \\
Stocker et al. (20I0) (HYDE) & 50 \\
Stocker et al. (20I0) (XI) & 153 \\
Kaplan et al. (this study) (KKI0) & $325-357$ \\
Kaplan et al. (this study) (HYDE) & $137-189$ \\
Lemmen (2009) & 54 \\
$\delta^{13}$ CO Mass Balance & \\
Elsig et al. (2009) & 50 \\
Ruddiman et al. (forthcoming) & $310-395$ \\
\hline
\end{tabular}

a Estimate of 'natural vegetation' of a pre-agricultural world minus late twentieth-century vegetation.

${ }^{b}$ Based on conversion of vegetation reconstructions of Matthews (1983) and Leemans and Cramer (1991).

rotation has the effect of increasing emissions slightly, but the overall trend of carbon emissions stays the same (Table 2, Figure 5). As the carbon emissions resulting from a land use rotation of 50 years are intermediate between no rotation (continuous cultivation of the same plot of land) and a 25 year rotation time, we describe these results here as our standard scenario.

LPJ runs using the KK10 data set compared with the control (natural vegetation) scenario indicate that ALCC emissions prior to $3 \mathrm{ka}$ ranged from 84 to $102 \mathrm{Pg} \mathrm{C}$ (Table 2, Figure 5). However, when using the HYDE scenario, LPJ simulates only 13 to $30 \mathrm{Pg}$ carbon emissions due to ALCC over this entire time period. The HYDE scenario appears relatively stable at roughly $30 \mathrm{Pg} \mathrm{C}$ cumulative emissions from ALCC (3400 Pg C total in global terrestrial ecosystems; Table 3) from $1000 \mathrm{BC}$ until $\sim \mathrm{AD} 1000$, where emissions from ALCC finally start to increase slightly (Tables 2 and 3, Figure 5). Emissions from ALCC simulated with the KK10 scenario increase continuously from 8 ka until roughly AD 200, where there is a 300 year period of stable or slightly decreasing emissions, followed by increasing emissions to $\sim \mathrm{AD} 1350$ where there is another short period of uptake coincident with the Black Death epidemic in Europe. Slight dips in emissions during these two European events are also visible in the HYDE results.

After $\mathrm{AD}$ 1350, ALCC emissions increase in the KK10 scenario to $\mathrm{AD} 1500$, when the collapse of indigenous populations in the Western Hemisphere led to widespread land abandonment. The following century between $\mathrm{AD} 1500$ and 1600 is marked by a $\sim 40 \mathrm{Pg}$ uptake of carbon into the terrestrial biosphere. Rates of carbon sequestration into the terrestrial biosphere reach more than $0.3 \mathrm{Pg} \mathrm{C} / \mathrm{yr}$ (Figure 5) in the KK10 scenario. No uptake of carbon is evident, at least on a global scale, in the HYDE-based scenarios 
for this time period (Figure 5). During the last 200 years of our model runs (AD 1650 to 1850) carbon emissions reach similar rates for both ALCC data sets (Figure 5), as total emissions reach $166 \mathrm{Pg} \mathrm{C}$ for the HYDE scenario and $343 \mathrm{Pg} \mathrm{C}$ for the KK10 scenario. The KK10 scenario runs result in a much higher total preindustrial emissions because of the larger magnitude of prehistoric ALCC emissions

Table 4 presents preindustrial emissions from ALCC from a number of other studies. The carbon emission numbers derived in this analysis are substantially higher than those from most previous simulations. For the preindustrial era, previous estimates have ranged between 48 and $153 \mathrm{Pg} \mathrm{C}$, whereas our simulations based on the KK10 and HYDE data sets indicate that releases of 325$357 \mathrm{Pg} \mathrm{C}$ and 137-189 Pg C could have occurred, respectively.

\section{Discussion}

Large differences between the two ALCC data sets in this study highlight the remarkable amount of uncertainty in estimating the magnitude and overall trend of Holocene ALCC. Though both methods rely heavily on population data to estimate ALCC, the $<1$ ha per capita preindustrial (before AD 1850) values implemented by HYDE result in conservative land use estimates, whereas the non-linear relationship used to create the KK10 data set implies a Boserupian view of fast expansion of anthropogenic land use at low population densities, with progressive intensification of land use as population pressure increases (Kaplan et al., 2009; Ruddiman and Ellis, 2009). Per capita land use estimates in KK10 are significantly higher than those of HYDE, with rough estimates by Ruddiman and Ellis (2009) providing a middle ground (Figure 2). The two methods used in this study result in ALCC estimates that are strikingly different (Figure 3), and portray an upper bound (KK10) and a lower bound (HYDE) to the range of uncertainty that exists for Holocene ALCC.

Much of the uncertainty around the extent of past land use comes from the lack of knowledge about the magnitude and distribution of the global human population and the time course of technological evolution and intensification. While global population estimates at $3 \mathrm{ka}$ differ by more than a factor of four (range 50-225 $\times 10^{6}$; see, e.g. Boyle et al., 2010, this issue; Dearing, 2006), estimates of the level of intensity with which humans use land are also highly uncertain. In the following sections, we discuss our results in the context of previous attempts to quantify Holocene ALCC carbon emissions, both from modeling and topdown estimates and we provide evidence to support our model simulations based on the ice core record of atmospheric $\mathrm{CO}_{2}$ concentrations and $\delta^{13} \mathrm{CO}_{2}$. Finally we assess the possibility of evaluating our simulations in light of the paleoecological and other proxy records.

\section{Uncertainities and comparisons with other studies}

The differences in estimates of preindustrial emissions between the KK10 scenario and other studies (Table 4) result mainly from higher amounts of prehistoric land use simulated in this ALCC scenario, but could also result from a number of other factors, including differences in estimates of the size of past human populations (see, e.g. Boyle et al., 2010, this issue), and variability in the carbon density of natural vegetation in regions where natural forests were converted to agriculture. In general, previous estimates of preindustrial carbon emissions from ALCC appear to be substantial underestimates resulting from the assumption that per capita land use has remained constant for the past 8000 years, an assumption not in agreement with observations (Boserup, 1965, 1981; Chao, 1986; Ellis and Wang, 1997; Ruddiman and Ellis, 2009; Ruddiman et al., forthcoming).

Dissimilarities between our results using the HYDE land use scenario and other studies based on HYDE (e.g. Strassmann et al., 2008) can be attributed to our choice of driver data sets and the modified LPJ setup described in the section 'Model configuration for ALCC simulations'. We also used a higher spatial resolution for simulations $\left(0.5^{\circ}\right)$ than some prior HYDE-based studies (e.g. $3.75^{\circ} \times 2.5^{\circ}$; Strassmann et al., 2008), avoiding errors caused by spatial averaging in heterogeneous regions (coastal, mountains, etc.). Our modeling system differentiates between pristine lands and lands recovering from previous ALCC; including this regrowing fraction causes greater carbon emissions earlier in time, as more of the land area is (or has been) under human influence at any given time. In contrast, our treatment of pastureland use could result in overestimates of ALCC emissions. Here, $100 \%$ of woody vegetation is removed on pastureland; leaving residual patches of natural vegetation, e.g. in a low intensity pasture landscape, would result in lower overall emissions, though we expect this effect to be much smaller than the effects of shifting cultivation and progressive land degradation. Also, the updated soil and climate data sets (supplementary methods) used in this study could lead to differences in natural carbon compared with other studies, though these effects are likely to be small over the long timescales considered here (Jung et al., 2007).

A substantial reason for the range of global carbon change estimates is uncertainty in assessing how much carbon is stored in 'natural' vegetation (Olson et al., 1983). For example, an early synthesis by Bazilevich et al. (1971) cites a global value of 1080 $\mathrm{Pg}$ in living biomass under conditions undisturbed by humans. A number of more recent modeling studies that ignore preindustrial ALCC resulted in simulations of peak Holocene terrestrial C storage (plants and surface soils) of 1600-2500 Pg (Cramer et al., 2001; Kaplan et al., 2002; McGuire et al., 2001; Sitch et al., 2003), with about one-third of total $\mathrm{C}$ stored in living biomass. Olson et al. (1983) point out that modern forests are likely to be degraded carbon-poor versions of pristine forests. Of the few 'natural' forest patches that remain, most have survived because they were in terrain too remote, steep, or otherwise uneconomical to be cut, and their carbon density would thus be lower than in the more productive lowland soils used first for agriculture and pasture (Ellis and Ramankutty, 2008). Other forests in parks or forest reserves were previously cut and, in the absence of management, would take centuries to recover to a natural state (Hermy and Verheyen, 2007). Still others have been degraded by humans seeking firewood or by frequent incursions of livestock.

Anthropogenic deforestation, followed by soil erosion, and land degradation, may have even resulted in irreversible ecological shifts and influenced regional climate patterns. For example, in the summer-monsoon regions of southern Asia, ALCC is hypothesized to have been responsible for a weakening in recycling of moisture by evapotranspiration, and a subsequent reduction in carbon density in the surviving woodland patches (Takata et al., 2009).

In the Mediterranean region, ALCC may have also resulted in regional climate changes and shifts from forest to shrubland vegetation even in areas that were later abandoned (de Beaulieu et al., 2005; Dümenil Gates and Ließ, 2001; Grove and Rackham, 
2001a; Tinner et al., 2009; Van der Knaap and van Leeuwen, 1995). This effect of land degradation preventing the establishment of climatically potential natural vegetation is not handled in the current modeling study, though all of the abovementioned effects would lead to increased cumulative ALCC emissions over the Holocene. In this sense, our estimates of ALCC emissions may still represent an underestimate, particularly for those regions of the world where long-term land degradation is observed, e.g. the Mediterranean basin (Grove and Rackham, 2001b).

Aside from sequestration of carbon in peatlands (Yu, forthcoming), natural changes in terrestrial carbon storage over the Holocene would have been small compared with anthropogenic effects. The expansion and contraction of the Afro-Asian monsoon system did not result in significant afforestation, rather being a dynamic between desert and sparsely vegetated steppe and xerophytic shrubland (Brovkin et al., 2002; Hoelzmann et al., 1998). In other parts of the world, climatic influences on vegetation cover were small (Wanner et al., 2008), and globally terrestrial ecosystems were generally carbon neutral between $8 \mathrm{ka}$ and preindustrial, with respect to climate (Figure S2; Kaplan et al., 2002).

In simulations with the KK10 data set, a significant uptake of carbon as a result of ALCC ( 40 Pg) is observed following European contact with indigenous populations of the Western Hemisphere (c. AD 1500 to 1600). A study by Pongratz et al. (forthcoming) rejects the hypothesis that historical events such as the demographic collapse of populations in the Americas substantially impacted atmospheric $\mathrm{CO}_{2}$, because of (1) delayed temporal dynamics of regrowth, (2) increased soil respiration from past ALCC, (3) continued ALCC in other parts of the world, and (4) counteracting responses of global carbon pools. However, according to the KK10 scenario, Central and South America were already highly deforested by $3 \mathrm{ka}$ (Figure 3), and most of the soil carbon from the original forests would have decomposed long before European contact, especially in the tropics where decomposition is fast (Chambers et al., 2000; Trumbore, 2000). Though forests in temperate regions of North America took longer to recover (Denevan, 1992), in the high productivity regions of tropical America, forest growth progresses quickly, especially during early stages of growth, some species fixing more than 10 tons of carbon/ha per yr (Faust et al., 2006; Riaño et al., 2002). Lastly, the massive regrowth of these forests would unlikely have been balanced by ALCC in other parts of the world because other areas with high population densities such as Europe and China, were highly deforested and experienced demographic and climatic crises during this period (e.g. the fall of the Ming Dynasty in China, 'Little Ice Age') which also resulted in periods of afforestation.

\section{The ice core record of Holocene $\mathrm{CO}_{2}$ and isotope mass balance constraints on ALCC emissions}

The ice core record of atmospheric $\mathrm{CO}_{2}$ concentrations over the Holocene (Figure 1) displays a number of features that may be correlated with changes in the simulated record of ALCC emissions when using the KK10 scenario (Figure 5). Making a direct comparison between these records is incorrect, however, because our model simulations omit other major elements of the global carbon cycle that are known to have changed over the Holocene, including ocean chemistry, coral reefs, and peatlands. Nevertheless it is illustrative to note some of the periods of correspondence between the curves. The KK10 simulations show a rapid increase in ALCC emissions between $8 \mathrm{ka}$ and roughly $3 \mathrm{ka}$, corresponding with the increase in $\mathrm{CO}_{2}$ concentrations over this time period. The simulated emissions of up to $100 \mathrm{Pg}$ can explain just under half of the $\sim 15 \mathrm{ppm}$ increase in atmospheric $\mathrm{CO}_{2}$ over this time period. We cannot directly assess the hypothesis that anthropogenic activities precluded glacial inception in the late Holocene (Ruddiman, 2007) but the ALCC emissions we simulate would likely have contributed to the increase in $\mathrm{CO}_{2}$ concentrations during the key time period after 8 ka when insolation forcing favored a return to glacial conditions.

Between $3 \mathrm{ka}$ and about AD 300 (1.65 ka) ALCC emissions continue to rise steadily and at a higher rate compared with the earlier Holocene (Figure 5), while very little variability is observed in atmospheric $\mathrm{CO}_{2}$ (Figure 1). The small reduction in emissions in $\mathrm{AD}$ 300-500 (the Migration Period in Europe) may be correlated with a very small drop in atmospheric $\mathrm{CO}_{2}$ concentrations around this time. More dramatic is the up to $10 \mathrm{ppm}$ drop in $\mathrm{CO}_{2}$ concentrations between $\mathrm{AD} 1500$ and 1700 (MacFarling Meure et al., 2006); this corresponds closely to the time of maximum carbon uptake as a result of land abandonment in the Western Hemisphere following European contact as discussed in the previous section. The $\sim 40 \mathrm{Pg}$ uptake of carbon we simulate during this time period can explain some of the drop in $\mathrm{CO}_{2}$ concentrations, and lends support to previous hypotheses on this topic (Nevle and Bird, 2008; Nevle et al., forthcoming; Ruddiman, 2005).

The carbon-isotope $\left(\delta^{13} \mathrm{C}\right)$ composition of $\mathrm{CO}_{2}$ in ice-core air bubbles can be used to assess net emissions/storage of terrestrial carbon during previous millennia. Elsig et al. (2009) measured a small negative $\delta^{13} \mathrm{CO}_{2}$ trend of $-0.03 \%$ over the last 7000 years, although one of the two methods they used indicated a larger ( $\sim 0.09 \%$ ) decrease. Based on carbon/ $\mathrm{CO}_{2}$ scaling from simulations with the Bern carbon cycle model (Joos et al., 2004), these $\delta^{13} \mathrm{CO}_{2}$ trends imply net terrestrial carbon emissions of $\sim 40-125 \mathrm{Pg}$ from $7 \mathrm{ka}$ to the start of the industrial era. Allowing for the effects of other natural factors $\left(\mathrm{CO}_{2}\right.$ fertilization, monsoon-related releases and storage of carbon, and carbon storage in peat), Elsig et al. (2009) estimated Holocene ALCC emissions of 50 Pg C. This amount, equivalent to a $\mathrm{CO}_{2}$ increase of $3.5 \mathrm{ppm}$, agrees with several of the estimates presented in Table 4. However, the assessment of Elsig et al. (2009) allows for only $40 \mathrm{Pg}$ of carbon storage in boreal peats over the last $7 \mathrm{ka}$, which has large implications for the allowable amount of ALCC emissions under isotope mass-balance constraints. Several studies suggest that this figure for Holocene peat accumulation could be a significant underestimate.

Bottom-up attempts to estimate the amount of carbon sequestered in peats over the Holocene result in a published range of $250-450 \mathrm{Pg}$ C (Frolking and Roulet, 2007; Gajewski et al., 2001; Gorham, 1991; MacDonald et al., 2006; Yu, forthcoming). These studies are based on syntheses of basal age of peats and simple to complex process modeling of peatland development. Yu (forthcoming) estimated that $\sim 270 \mathrm{Pg} \mathrm{C}$ were stored in boreal peatlands during the last 7000 years, consistent with estimates by Gorham (1991) and Gajewski et al. (2001). Ruddiman et al. (forthcoming) noted that this estimate would leave an unexplained difference of $\sim 310-395 \mathrm{Pg} \mathrm{C}$ between the large net burial of carbon in peats and the small net carbon release indicated by the $\delta^{13} \mathrm{CO}_{2}$ signal. The only remaining explanation for this unaccounted-for carbon appears to be anthropogenic emissions. All of the preindustrial estimates listed in Table 4 fall well short of explaining this 310-395 Pg residual except the 325-357 Pg C estimate we make here using the KK10 ALCC scenario as a driver. The small late-Holocene $\delta^{13} \mathrm{CO}_{2}$ decrease that has previously been 
interpreted as favoring a very small ( $\sim 50 \mathrm{Pg})$ input of anthropogenically derived terrestrial carbon during the last $7 \mathrm{ka}$ needs to be re-examined. If almost $300 \mathrm{Pg}$ of terrestrial carbon was sequestered in peatlands over this time period, explaining a net release of $\sim 40-125$ $\mathrm{Pg}$ of terrestrial carbon requires anthropogenic emissions far larger than the $50 \mathrm{Pg} \mathrm{C}$ value used by Elsig et al. (2009).

\section{Evaluation of the ALCC scenarios}

The lack of continental- to global-scale syntheses of evidence for human impact on the Earth's land surface makes it difficult at this point to perform anything more than a superficial, qualitative evaluation of our ALCC scenario results. Developing a continuous synthesis of global human impact at the regional level is currently a major focus of interdisciplinary research coordination, e.g. through the AIMES/PAGES IHOPE program. These ongoing efforts should be combined with existing surveys of human impact over the Holocene using multiple proxies (e.g. Dearing, 2006; Gaillard et al., 2010; Hellman et al., 2008; Sugita, 2007a, b), and with archaeological data syntheses (e.g. Weninger et al., 2006; Zimmermann et al., 2004) that have traditionally been overlooked by the natural science community. At the site scale, there is considerable paleoecological and archaeological evidence for early extensive human land use in, e.g. Andes (ChepstowLustry and Winfield, 2000), Mesoamerica (Pohl et al., 1996), Europe (Tinner et al., 2007), and China (Ren, 2000). While syntheses of charcoal records from remote areas of the globe attribute Holocene trends in biomass burning to climatic changes rather than ALCC (Marlon et al., 2008; Power et al., 2008), other regional syntheses (e.g. McWethy et al., 2009; Nevle and Bird, 2008) show that biomass burning correlates strongly with the rise and fall of human societies.

\section{Future perspectives and conclusions}

Holocene carbon cycle modeling can be improved in multiple ways to achieve more accurate quantification of carbon balances throughout history. Differentiating among different types of land use systems (e.g. Ellis and Ramankutty, 2008; Verburg et al., 2009), would improve the quality of our carbon budget simulations by allowing us to simulate a more diverse suite of land use patterns (e.g. managed and unmanaged rangelands, managed forests). A future implementation of our ALCC model should have a spatially variable scheme for land rotation based on climate and soil fertility, so that in places where soils are exhausted more quickly people are forced to use more land, implementing, e.g. a short 3-5 year rotation-time shifting cultivation in the tropics. Also, accounting for improvements in technology (e.g. the development of irrigation or heavy steel plows) by having a spatially and temporally dynamic agricultural land suitability data set would allow us to better simulate the spatial distributions of land use over time.

Running the DGVM with a transient Holocene climate scenario, either modeled or reconstructed, could help improve the realism of the simulations by accounting for the shifts in terrestrial $\mathrm{C}$ caused by climate change, e.g. following the Holocene development and subsequent collapse of the 'green Sahara' or the advance and retreat of the polar timberline. Ultimately, when used in a coupled mode, our ALCC scenarios would allow investigation of feedbacks between climate, carbon and land use and the potential to address questions on human-induced irreversible ecosystem shifts caused by perturbations to the vegetation-climate system. Finally, a number of efforts are currently underway to improve the functionality of DGVMs to more accurately model global carbon exchanges, e.g. by including a representation of peatland dynamics or using more plant functional types. All of these improvements will help achieve more realistic modeling designs towards the central goal of obtaining a more precise representation of past carbon cycles. This will contribute to a better understanding of the role of humans in the earth system and the present and future states of the global carbon cycle.

ALCC models that include land use intensification in response to population pressure and improvements in agricultural technologies (Ruddiman and Ellis, 2009) result in much higher estimates of ALCC and carbon release in prehistoric times than do studies that assume relatively constant per capita land use based on twentieth century values. As a result, our estimates of ALCC-driven carbon emissions are substantially higher than previous studies. However, considering the range of estimates for carbon sequestration in peats during the Holocene, our ALCC emission estimates are compatible with the $\delta^{13} \mathrm{CO}_{2}$ record, and allow us to explain Holocene carbon dynamics that cannot be attributed to other natural processes.

Carbon emissions as a result of anthropogenic land use over the preindustrial Holocene could have had a very substantial impact on the global carbon cycle. Even before 1000 BC (3 ka), up to $102 \mathrm{Pg}$ of carbon could have been emitted into the atmosphere caused by human land use. This amount of carbon could have contributed to, but cannot fully explain, the increase in atmospheric $\mathrm{CO}_{2}$ that occurred over the middle Holocene. By AD 1850, this amount increases to roughly $360 \mathrm{Pg}$, which equates to a $\sim 25$ ppm increase in atmospheric $\mathrm{CO}_{2}$. In this sense, our results favor far larger early anthropogenic carbon emissions than previous estimates (which are a factor of 3-7 smaller). This is a substantial fraction of the amount posed in the original early anthropogenic hypothesis (Ruddiman, 2003). As a result, the world is much warmer than it would otherwise be.

\section{Acknowledgements}

This research was supported by grants from the Swiss National Science Foundation (PP0022_119049) and the Italian Ministry for Research and Education (FIRB RBID08LNFJ). C.L. was supported by Deutsche Forschungsgemeinschaft (DFG, priority program Interdynamik SPP-1266). The authors thank Junmei Hu for assistance in interpreting Chinese population data, Navin Ramankutty for helpful discussions, and two anonymous reviewers, whose comments improved this manuscript.

\section{References}

Bazilevich NI, Rodin LY and Rozov NN (1971) Geographical aspects of biological productivity. Soviet Geography: Review and Translation 12: 293-317.

Bellwood P (2005) First Farmers: The Origins of Agricultural Societies. Oxford: Blackwell Publishing.

Boserup E (1965) The Conditions of Agricultural Growth: The Economics of Agrarian Change Under Population Pressure. Chicago: Aldine.

Boserup E (1981) Population and Technological Change: A Study of Long Term Trends. Chicago: University of Chicago Press.

Boyle JF, Gaillard MJ, Kaplan JO and Dearing JA (2010) Modelling prehistoric land use and carbon budgets: A critical review. The Holocene (this issue). doi: 10.1177/0959683610386984. 
Brovkin V, Bendtsen J, Claussen M, Ganopolski A, Kubatzki C, Petoukhov V et al. (2002) Carbon cycle, vegetation, and climate dynamics in the Holocene: Experiments with the CLIMBER-2 model. Global Biogeochemical Cycles 16: doi:10.1029/2001GB001662.

Chambers JQ, Higuchi N, Schimel JP, Ferreira LV and Melack JM (2000) Decomposition and carbon cycling of dead trees in tropical forests of the central Amazon. Oecologia 122: 380-388.

Chao K (1986) Man and Land in Chinese History: An Economic Analysis. Stanford University Press.

Chepstow-Lustry A and Winfield M (2000) Inca agroforestry: Lessons from the past. Ambio 29: 322-328.

Cook OF (1921) Milpa agriculture, a primitive tropical system. Smithsonian Institution Annual Report 1919: 307-326.

Cramer W, Bondeau A, Woodward FI, Prentice C, Betts RA, Brovkin V et al. (2001) Global response of terrestrial ecosystem structure and function to $\mathrm{CO}_{2}$ and climate change: Results from six dynamic global vegetation models. Global Change Biology 7: 357-374.

de Beaulieu J-L, Miras Y, Andrieu-Ponel V and Guiter F (2005) Vegetation dynamics in north-western Mediterranean regions: Instability of the Mediterranean bioclimate. Plant Biosystems 139: 114-126.

Dearing JA (2006) Climate-human-environment interactions: Resolving our past. Climate of the Past 2: 187-203.

DeFries RS, Field CB, Fung I, Collatz GJ and Bounoua L (1999) Combining satellite data and biogeochemical models to estimate global effects of human-induced land cover change on carbon emissions and primary productivity. Global Biogeochemical Cycles 13: 803-815.

Denevan WM (1992) The Pristine Myth: The landscape of the Americas in 1492. Annals of the Association of American Geographers 82: 369-385.

Dümenil Gates L and Ließ S (2001) Impacts of deforestation and afforestation in the Mediterranean region as simulated by the MPI atmospheric GCM. Global and Planetary Change 30: 309-328.

Ellis EC and Ramankutty N (2008) Putting people in the map: Anthropogenic biomes of the world. Frontiers in Ecology and the Environment 6: $439-447$.

Ellis EC and Wang SM (1997) Sustainable traditional agriculture in the Tai Lake region of China. Agricultural Systems and Environment 61: 177-193.

Elsig J, Schmitt J, Leuenberger D, Schneider R, Ever M, Leuenberger F et al. (2009) Stable isotope constraints on Holocene carbon cycle changes from an Antarctic ice core. Nature 461: 507-510.

Ervynck A, Lentacker A, Müldner G, Richards M and Dobney K (2007) An investigation into the transition from forest dwelling pigs to farm animals in medieval Flanders, Belgium. In: Albarella U, Dobney K and Ervynck A (eds) Pigs and Humans: 10,000 Years of Interaction. Oxford: Oxford University Press, 171-193.

Faust FX, Gnecco C, Mannstein H and Stamm J (2006) Evidence for the postconquest demographic collapse of the Americas in historical $\mathrm{CO}_{2}$ levels. Earth Interactions 10: 1-14.

Frolking S and Roulet NT (2007) Holocene radiative forcing impact of northern peatland carbon accumulation and methane emissions. Global Change Biology 13: 1079-1088.

Gaillard M-J, Sugita S, Mazier F, Kaplan JO, Trondman A-K, Broström A et al. (2010) Holocene land-cover reconstructions for studies on land coverclimate feedbacks. Climate of the Past Discussions 6: 307-346.

Gajewski K, Viau A, Sawada M, Atkinson D and Wilson S (2001) Sphagnum peatland distribution in North America and Eurasia during the past 21,000 years. Global Biogeochemical Cycles 15: 297-310.

Gorham E (1991) Northern peatlands: Role in the carbon cycle and probable responses to climatic warming. Ecological Applications 1: 182-195.

Grove AT and Rackham O (2001a) Natural vegetation in historic times. In: Havell J (ed.) The Nature of Mediterranean Europe: An Ecological History. New Haven: Yale University Press.
Grove AT and Rackham O (2001b) The Nature of Mediterranean Europe: An Ecological History. New Haven and London: Yale University Press.

Hellman SEV, Gaillard M-J, Bröstrom A and Sugita S (2008) Effects of the sampling design and selection of parameter values on pollen-based quantitative reconstructions of regional vegetation: A case study in southern Sweden using the REVEALS model. Vegetation History and Archaeobotany 17: 445-459.

Hermy M and Verheyen K (2007) Legacies of the past in the present-day forest biodiversity: A review of past land-use effects on forest plant species composition and diversity. Ecological Research 22: 361-371.

Hoelzmann P, Jolly D, Harrison SP, Laarif F, Bonnefille R and Pachur HJ (1998) Mid-Holocene land-surface conditions in northern Africa and the Arabian Peninsula: A data set for the analysis of biogeophysical feedbacks in the climate system. Global Biogeochemical Cycles 12: 35-51.

Houghton JT, Hackler JL and Lawrence KT (1999) The U.S. carbon budget: Contributions from land-use change. Science 285: 574-578.

Houghton RA (2003) Revised estimates of the annual net flux of carbon to the atmosphere from changes in land use and land management 1850-2000. Tellus 55B: 378-390.

Johnston KJ (2003) The intensification of pre-industrial cereal agriculture in the tropics: Boserup, cultivation lengthening, and the Classic Maya. Journal of Anthropological Archaeology 22: 126-161.

Joos F, Gerber S, Prentice IC, Otto-Bliesner BL and Valdes P (2004) Transient simulations of Holocene atmospheric carbon dioxide and terrestrial carbon since the last glacial maximum. Global Biogeochemical Cycles 18: GB2002 2010.1029/2003GB002156.

Jung M, Vetter M, Herold M, Churkina G, Reichstein M, Zaehle S et al. (2007) Uncertainties of modeling gross primary productivity over Europe: A systematic study on the effects of using different drivers and terrestrial biosphere models. Global Biogeochemical Cycles 21: doi:10.1029/2006GB002915.

Kaplan JO (2001) Geophysical Applications of Vegetation Modeling. Department of Ecology, Lund: Lund University, 132 pp.

Kaplan JO, Prentice IC, Knorr W and Valdes PJ (2002) Modeling the dynamics of terrestrial carbon storage since the Last Glacial Maximum. Geophysical Research Letters 29: doi:10.1029/2001GB001403.

Kaplan JO, Krumhardt KM and Zimmerman N (2009) The prehistoric and preindustrial deforestation of Europe. Quaternary Science Reviews 28: 3016-3034.

Klein Goldewijk K (2001) Estimating global land use change over the past 300 years: The HYDE Data base. Global Biogeochemical Cycles 15: 417-433.

Klein Goldewijk K, Beusen A and Janssen P (2010a) Long-term dynamic modeling of global population and built-up area in a spatially explicit way, HYDE 3.1. The Holocene 20: 565-573.

Klein Goldewijk K, Beusen A, van Drecht G and de Vos M (2010b) The HYDE 3.1 spatially explicit data base of human induced global land use change over the past 12,000 years. Global Ecology \& Biogeography doi:10.1111/ j.1466-8238.2010.00587.x, in press.

Krumhardt KM (2010) ARVE Technical Report \#3: Methodology for worldwide population estimates: 1000 BC to 1850 . École Polytechnique Fédérale de Lausanne, Dept. of Environmental Engineering, ARVE Research Group, http://arve.epfl.ch/technical_reports/ARVE_tech_report3_pop_methods.pdf.

Krumhardt KM and Kaplan JO (2010) ARVE Technical Report \#2: A spline fit to atmospheric $\mathrm{CO}_{2}$ records from Antarctic ice cores and measured concentrations for the past 25,000 years. Environmental Engineering Institute, Ecole Polytechnique Fédérale de Lausanne, http://arve.epfl.ch/technical_ reports/ARVE_tech_report2_co2spline.pdf.

Leemans R and Cramer WR (1991) The IIASA Data base for Mean Monthly Values of Temperature, Precipitation, and Cloudiness on a Global Terrestrial Grid. Laxenburg, Austria: International Institute for Applied Systems Analysis. 
Lemmen C (2009) World distribution of land cover changes during Preand Protohistoric times and estimation of induced carbon releases. Géomorphologie: relief, processus, environnement 4(2009): 303-312.

MacDonald GM, Beilman DW, Kremenetski KV, Sheng Y, Smith LC and Velichko AA (2006) Rapid early development of circumarctic peatlands and atmospheric $\mathrm{CH}_{4}$ and $\mathrm{CO}_{2}$ variations. Science 314: 285-288.

MacFarling Meure C, Etheridge DM, Trudinger C, Steele LP, Langenfelds RL, van Ommen $\mathrm{T}$ et al. (2006) The Law Dome $\mathrm{CO}_{2}, \mathrm{CH}_{4}$, and $\mathrm{N}_{2} \mathrm{O}$ ice core records extended to 2000 year BP. Geophysical Research Letters 33: L14810 14810.11029/12006GL026152.

Marlon JR, Bartlein PJ, Carcaillet C, Gavin DG, Harrison SP, Higuera K et al. (2008) Climate and human influences on global biomass burning over the past two millennia. Nature Geoscience 1: 697-702.

Mathey RT and Gurr DL (1983) Variation in prehistoric agricultural systems of the New World. Annual Review of Anthropology 12: 79-103.

Matthews E (1983) Global vegetation and land use: New high-resolution data bases for climate studies. Journal of Climate and Applied Meteorology 22: 474-487.

Mazoyer M and Roudart L (2006) A History of World Agriculture. London: Earthscan.

McEvedy C and Jones R (1978) Atlas of World Population History. London: Penguin.

McGuire AD, Sitch S, Clein JS, Dargaville R, Esser G, Foley J et al. (2001) Carbon balance of the terrestrial biosphere in the twentieth century: Analyses of $\mathrm{CO}_{2}$, climate and land use effects with four process-based ecosystem models. Global Biogeochemical Cycles 15: 183-206.

McWethy DB, Whitlock C, Wilmshurst JM, McGlone MS and Li X (2009) Rapid deforestation of South Island, New Zealand, by early Polynesian fires. The Holocene 19: 883-897.

Nevle RJ and Bird DK (2008) Effects of syn-pandenic fire reduction and reforestation in the tropical Americas on atmospheric $\mathrm{CO}_{2}$ during European conquest. Palaeogeography, Palaeoclimatology, Palaeoecology 264: 25-38.

Nevle RJ, Bird DK, Ruddiman WF and Dull RA (forthcoming) Neotropical human landscape interactions, fire, and atmospheric $\mathrm{CO}_{2}$ during European conquest. The Holocene (this issue).

Olofsson J and Hickler T (2008) Effects of human land-use on the global carbon cycle during the last 6,000 years. Vegetation History and Archaeobotany 17: 605-615.

Olson JS, Watts JA and Allison J (1983) Carbon in Live Vegetation of Major World Ecosystems. ORNL 5862, Environmental Sciences Division Publ. No. 1997. Oak Ridge TN: Oak Ridge National Library.

Pohl MD, Pope KO, Jones JG, Jacob JS, Piperno DR, deFrance SD et al. (1996) Early agriculture in the Maya lowlands. Latin American Antiquity 7: 355-372.

Pongratz J, Reick C, Raddatz T and Claussen M (2008) A reconstruction of global agricultural areas and land cover for the last millennium. Global Biogeochemical Cycles 22: doi:10.1029/2007GB003153.

Pongratz J, Reick C, Raddatz T and Claussen M (2009) Effects of anthropogenic land cover change on the carbon cycle of the last millennium. Global Biogeochemical Cycles 23: GB4001, doi:4010.1029/2009GB003488.

Pongratz J, Caldeira K, Reick $\mathrm{CH}$ and Claussen M (forthcoming) Coupled climate-carbon simulations indicate minor effects of wars and epidemics on atmospheric $\mathrm{CO}_{2}$ between $\mathrm{AD} 800$ and 1850. The Holocene (this issue). doi: 10.1177/0959683610386981.

Power M, Marlon J, Ortiz N, Bartlein P, Harrison S, Mayle F et al. (2008) Changes in fire regimes since the Last Glacial Maximum: An assessment based on a global synthesis and analysis of charcoal data. Climate Dynamics 30: 887-907.

Ramankutty N and Foley J (1998) Characterizing patterns of global land use: An analysis of global croplands data. Global Biogeochemical Cycles 12: $667-685$.
Ramankutty N and Foley JA (1999) Estimating historical changes in global land cover: Croplands from 1700 to 1992. Global Biogeochemical Cycles 13: 997-1027.

Ramankutty N, Foley JA, Norman J and McSweeney K (2002) The global distribution of cultivatable lands: Current patterns and sensitivity to possible climate change. Global Ecology \& Biogeography 11: 377-392.

Reina RE (1967) Milpas and milperos: Implications for prehistoric times. American Anthropologist, New Series 69: 1-20.

Ren G (2000) Decline of the mid- to late Holocene forests in China: Climatic change or human impact? Journal of Quaternary Science 15: 273-281.

Riaño NM, Londoño X, López Y and Gómez JH (2002) Plant growth and biomass distribution on Guadua angustifolia Kunth in relation to aging in the Valle del Cauca-Colombia. Bamboo Science and Culture 16: 43-51.

Richerson PJ, Boyd R and Bettinger RL (2001) Was agriculture possible during the Pleistocene but mandatory during the Holocene? A climate change hypothesis. American Antiquity 66: 387-411.

Ruddiman WF (2003) The anthropogenic greenhouse era began thousands of years ago. Climatic Change 61: 261-293.

Ruddiman WF (2005) Plows, Plagues, and Petroleum: How Humans Took Control of the Climate. Princeton: Princeton University Press.

Ruddiman WF (2007) The early anthropogenic hypothesis: Challenges and responses. Reviews of Geophysics 45: doi:10.1029/2006RG000207.

Ruddiman WF and Ellis EC (2009) Effect of per-capita land-use changes on Holocene forest clearance and $\mathrm{CO}_{2}$ emissions. Quaternary Science Reviews 28: 3011-3015.

Ruddiman WF, Kutzbach JE and Vavrus SJ (forthcoming) Can natural or anthropogenic explanations of early Holocene $\mathrm{CO}_{2}$ and $\mathrm{CH}_{4}$ increases be falsified? The Holocene (this issue). doi: 10.1177/0959683610387172.

Sitch S, Smith B, Prentice IC, Arneth A, Bondeau A, Cramer W et al. (2003) Evaluation of ecosystem dynamics, plant geography and terrestrial carbon cycling in the LPJ dynamic global vegetation model. Global Change Biology 9: 161-185.

Stocker B, Strassmann K and Joos F (2010) Sensitivity of Holocene atmospheric $\mathrm{CO}_{2}$ and the modern carbon budget to early human land use: Analyses with a process-based model. Biogeosciences Discussion 7: 921-952.

Strassmann KM, Joos F and Fischer G (2008) Simulating effects of land use changes on carbon fluxes: Past contributions to atmospheric $\mathrm{CO}_{2}$ increases and future commitments due to losses of terrestrial sink capacity. Tellus 60B: 583-603.

Sugita S (2007a) Theory of quantitative reconstruction of vegetation I: Pollen from large sites REVEALS regional vegetation. The Holocene 17: 229-241.

Sugita S (2007b) Theory of quantitative reconstruction of vegetation II: All you need is LOVE. The Holocene 17: 243-257.

Takata K, Saito K and Yasunari T (2009) Changes in the Asian monsoon climate during 1700-1850 induced by preindustrial cultivation. PNAS 106: 9586-9589.

Tinner W, Nielsen EH and Lotter AF (2007) Mesolithic agriculture in Switzerland? A critical review of the evidence. Quaternary Science Reviews 26: 1416-1431.

Tinner W, van Leeuwen JFN, Colombaroli D, Vescovi E, Van der Knaap WO, Henne PD et al. (2009) Holocene environmental and climatic changes at Gorgo Basso, a coastal lake in southern Sicily, Italy. Quaternary Science Reviews 28: 1498-1510.

Trumbore S (2000) Age of soil organic matter and soil respiration: Radiocarbon constraints on belowground C dynamics. Belowground Processes and Global Change 10: 399-411.

Van der Knaap WO and van Leeuwen JFN (1995) Holocene vegetation succession and degradation as responses to climatic change and human activity in the Serra de Estrela, Portugal. Review of Palaeobotany and Palynology 89: 153-211. 
Verburg PH, van de Steeg J, Veldkamp A and Willemen L (2009) From land cover change to land function dynamics: A major challenge to improve land characterization. Journal of Environmental Management 90: 1327-1335.

Verheyen K, Bossuyt B, Hermy M and Tack G (1999) The land use history (1278-1990) of a mixed hardwood forest in western Belgium and its relationship with chemical soil characteristics. Journal of Biogeography 26: 1115-1128.

Wanner H, Beer J, Bütikofer J, Crowley TJ, Cubasch U, Flückiger J et al. (2008) Mid- to Late Holocene climate change: An overview. Quaternary Science Reviews 27: 1791-1828.

Weninger B, Alram-Stern E, Bauer E, Clare L, Danzeglocke U, Joris O et al. (2006) Climate forcing due to the 8200 cal yr BP event observed at Early Neolithic sites in the eastern Mediterranean. Quaternary Research 66: 401-420.
Wilken GC (1971) Food-producing systems available to the ancient Maya. American Antiquity 36: 432-448.

Williams M (2008) A new look at global forest histories of land clearing. Annual Review of Environment and Resources 33: 345-367.

Wirtz KW and Lemmen C (2003) A global dynamic model for the Neolithic transition. Climatic Change 59: 333-367.

Yu Z (forthcoming) Holocene carbon flux histories of the world's peatlands: Global carbon-cycle implications. The Holocene (this issue). doi: $10.1177 / 0959683610386982$.

Zhao W and Xie S (1988) History of Population in China (Zhongguo Ren Kou Shi). Beijing: People's Publishing House.

Zimmermann A, Richter J, Frank T and Wendt K-P (2004) Landschaftsarchäologie II - Überlegungen zu Prinzipien einer Landschaftsarchäologie. Berichte der Römisch-Germanischen Komission 85: 37-96. 